NBER WORKING PAPER SERIES

\author{
A MATTER OF TRUST: \\ UNDERSTANDING WORLDWIDE PUBLIC PENSION CONVERSIONS \\ Kent Smetters \\ Walter E. Theseira \\ Working Paper 17015 \\ http://www.nber.org/papers/w17015
}

\author{
NATIONAL BUREAU OF ECONOMIC RESEARCH \\ 1050 Massachusetts Avenue \\ Cambridge, MA 02138
}

May 2011

This research was supported by the U.S. Social Security Administration through grant \#10-P-98363-1-05 to the National Bureau of Economic Research as part of the SSA Retirement Research Consortium. The findings and conclusions expressed are solely those of the author(s) and do not represent the views of SSA, any agency of the Federal Government, or the NBER. The views expressed herein are those of the authors and do not necessarily reflect the views of the National Bureau of Economic Research.

NBER working papers are circulated for discussion and comment purposes. They have not been peerreviewed or been subject to the review by the NBER Board of Directors that accompanies official NBER publications.

(C) 2011 by Kent Smetters and Walter E. Theseira. All rights reserved. Short sections of text, not to exceed two paragraphs, may be quoted without explicit permission provided that full credit, including (c) notice, is given to the source. 
A Matter of Trust: Understanding Worldwide Public Pension Conversions

Kent Smetters and Walter E. Theseira

NBER Working Paper No. 17015

May 2011

JEL No. H0,H55

\begin{abstract}
$\underline{\text { ABSTRACT }}$
This paper seeks to explain the key two stylized facts of fundamental reforms to social security systems worldwide: Why have so many countries reformed when traditional systems seem, at first glance, to have a higher probability of delivering a secure retirement income? Why have these reforms been larger in developing countries facing less severe demographic problems? We show that an OLG voter model can answer both questions. Larger reforms are motivated by a fundamental breakdown in intergenerational trust while smaller reforms are caused by a lack of trust in the ability of the government to save. Empirical analysis seems to support the model.
\end{abstract}

Kent Smetters

University of Pennsylvania

SH-DH 3303

3620 Locust Walk

Philadelphia, PA 19104

and NBER

smetters@wharton.upenn.edu

Walter E. Theseira

Nanyang Technological University

HSS-04-49, 14 Nanyang Drive

Singapore 637332

Republic of Singapore

wetheseira@ntu.edu.sg 


\title{
A MATTER OF TRUST: UNDERSTANDING WORLDWIDE PUBLIC PENSION CONVERSIONS $^{1}$
}

\author{
Kent Smetters, University of Pennsylvania, and NBER \\ Walter Theseira, Nanyang Technological University ${ }^{2}$
}

\begin{abstract}
This paper seeks to explain the key two stylized facts of fundamental reforms to social security systems worldwide: Why have so many countries reformed when traditional systems seem, at first glance, to have a higher probability of delivering a secure retirement income? Why have these reforms been larger in developing countries facing less severe demographic problems? We show that an OLG voter model can answer both questions. Larger reforms are motivated by a fundamental breakdown in intergenerational trust while smaller reforms are caused by a lack of trust in the ability of the government to save. Empirical analysis seems to support the model.
\end{abstract}

Keywords: Social Security, Trust

JEL Codes: H0, H55, D7

1. $\quad$ Introduction

One of the most far-reaching shifts in fiscal policy worldwide during the past two decades has been the fundamental restructuring of public pension systems. At least 28 countries spanning five continents have converted, partially or completely, from pay-as-yougo defined-benefit public pension systems to systems based on funded, defined-contribution accounts. Reforms appear to be imminent in several more countries, while other countries like the United States have seriously debated converting their public pension systems as well.

These conversions are potentially the most significant policy reform during the past century. Such a claim might at first seem to be a stretch. There have been many large public

\footnotetext{
${ }^{1}$ This research was supported by the U.S. Social Security Administration through grant \#10-P-98363-1-05 to the National Bureau of Economic Research as part of the SSA Retirement Research Consortium. The findings and conclusions expressed are solely those of the author(s) and do not represent the views of SSA, any agency of the Federal Government, or the NBER.

${ }^{2}$ Smetters: smetters@wharton.upenn.edu. 3620 Locust Walk, SH-DH 3303 Philadelphia, PA 19104. 215-8989811. Theseira: wetheseira@ntu.edu.sg, 14 Nanyang Drive, HSS-04-49, Singapore 637332, Republic of Singapore. Parts of this paper were written with Cindy Park while at the U.S. Treasury in the years 2000-1. We thank Robert Palacios and participants at the NBER Summer meetings and the ASSA meetings for helpful comments.
} 
policy changes during the past century: Trade barriers have been curtailed; price controls have been dropped across many sectors; major industries have been deregulated; and, high tax rates levied on narrow bases have been replaced with lower, broad-based taxes. But their gains likely pale in comparison to pension reform.

Previous simulation analyses suggests that moving the United States Social Security system from pay-as-you-go financing to full funding could produce as much as a 30 percent or more increase in the size of capital stock as well as increase potential (full) lifetime income by over 20 percent. ${ }^{3}$ These potential gains are much larger than those associated with fundamentally reforming the US federal income tax (Altig et al 2000), and potentially larger than most other types of fiscal reforms, including even the adoption of free trade. ${ }^{4}$

While pension fund conversions from defined benefit (DB) to defined contribution (DC) plans in the private sector have been largely motivated improving labor market mobility within a country, this explanation does not hold for public pension systems. In fact, the public plan conversions seem fairly puzzling at first glance. A traditional public DB plan can be funded like a standard DC plan. Moreover, in the presence of economic uncertainty, traditional plans more easily allow for inter-generational risk sharing. The additional problems of financial illiteracy, moral hazard and adverse selection seem only to buttress the case for the traditional pension system.

This paper examines the two key stylized puzzles of pension reform. First, why have so many countries moved, or are in the process of moving, away from unfunded DB plans towards at least partially funded DC plans? Second, why have these reforms typically have

\footnotetext{
${ }^{3}$ Nishiyama and Smetters (2007) reviews the literature.

${ }^{4}$ See Baldwin (1992) for estimates of the dynamic gains from trade liberalization.
} 
been larger in developing countries, which don't face the same severe demographic problems motivating the reform debate in developed countries?

Table 1 gives an overview of reforming countries: the date of reform, the degree of privatization and whether participation in the reformed system was voluntary or required. To estimate the degree of privatization, we developed an actuarial model for each country that incorporates that country's specific reform rules, income distribution, life expectancy and other key economic and demographic variables (Appendix B). The degree of privatization is then calculated by estimating the annuitized fraction of retirement benefits provided by the new defined contribution system relative to total benefits for the median worker. Figure 1 plots the reform size against the per-capita income for each country. Notice that larger reforms typically occur in countries with lower per-capita income.

Table 1

\begin{tabular}{|l|c|c|l|}
\hline \multicolumn{1}{|c|}{ Country } & $\begin{array}{c}\text { Year Personal } \\
\text { Accounts } \\
\text { Introduced }\end{array}$ & $\begin{array}{c}\text { Percent of Retirement } \\
\text { Benefit from Personal } \\
\text { Account after Reform for } \\
\text { Average Worker }\end{array}$ & \multicolumn{1}{|c|}{ Voluntary Participation Choice / Notes } \\
\hline \hline Chile & 1981 & $96.25 \%$ & $\begin{array}{l}\text { New workers must join new system; current } \\
\text { workers may choose between systems. }\end{array}$ \\
\hline Switzerland & 1982 & $62.87 \%$ & No. \\
\hline U.K. & 1986 & n.a & $\begin{array}{l}\text { Yes. Due to voluntary participation, } \\
\text { problems with private pension } \\
\text { administration, and rollbacks of the scheme, } \\
\text { the U.K. is treated as a non-reforming } \\
\text { country in our study. }\end{array}$ \\
\hline Peru & 1991 & $62.33 \%$ & Yes. \\
\hline Australia & 1992 & $71.69 \%$ & $\begin{array}{l}\text { No. } \\
\text { Argentina }\end{array} 1993$ \\
\hline Colombia & 1993 & $62.98 \%$ & $\begin{array}{l}\text { Yes. workers are allowed to switch back and } \\
\text { forth every three years. }\end{array}$ \\
\hline China & 1995 & $32.51 \%$ & $\begin{array}{l}\text { No. No unified national social security } \\
\text { system. Implementation of reforms varies } \\
\text { widely with substantial discretion by local } \\
\text { government. Therefore, China is treated as a } \\
\text { non-reforming country in our study. }\end{array}$ \\
\hline
\end{tabular}




\begin{tabular}{|c|c|c|c|}
\hline Mexico & 1995 & $98.87 \%$ & No. \\
\hline Uruguay & 1995 & $22.96 \%$ & $\begin{array}{l}\text { Employees over } 40 \text { years old can choose, } \\
\text { those under } 40 \text { years old and new workers } \\
\text { must join new system. }\end{array}$ \\
\hline El Salvador & 1996 & $90.97 \%$ & $\begin{array}{l}\text { All new and young workers must join new } \\
\text { system. Older workers must remain with old } \\
\text { system. Workers between } 36 \text { and } 55 \text { (men) / } \\
50 \text { (women) years old may choose. }\end{array}$ \\
\hline Bolivia & 1997 & $100.00 \%$ & No. \\
\hline Hungary & 1997 & $37.96 \%$ & No. \\
\hline Denmark & 1998 & $79.54 \%$ & No. \\
\hline Kazakhstan & 1998 & $100.00 \%$ & No. \\
\hline Poland & 1998 & $44.96 \%$ & Yes. \\
\hline Sweden & 1998 & $17.73 \%$ & $\begin{array}{l}\text { Workers born before } 1938 \text { stay with old } \\
\text { system; those born after } 1953 \text { switch to new } \\
\text { system; gradual transition from old to new } \\
\text { system for workers born between } 1938 \text { and } \\
1953 .\end{array}$ \\
\hline Croatia & 1999 & $31.48 \%$ & $\begin{array}{l}\text { Workers between age of } 40 \text { and } 50 \text { at the } \\
\text { time of reform can opt into the new system. } \\
\text { Older workers remain in old system, younger } \\
\text { workers must participate in new system. }\end{array}$ \\
\hline Costa Rica & 2000 & $7.92 \%$ & No. \\
\hline Bulgaria & 2000 & $24.39 \%$ & $\begin{array}{l}\text { All workers born after } 1959 \text { must participate } \\
\text { in the new system. }\end{array}$ \\
\hline Hong Kong & 2000 & n.a. & $\begin{array}{l}\text { No. Country is not sovereign self-governing } \\
\text { state. Therefore, country is not modeled and } \\
\text { not included in our dataset. }\end{array}$ \\
\hline Nicaragua & 2000 & $100.00 \%$ & $\begin{array}{l}\text { System implementation suspended in } 2005 \\
\text { and prior public pension system restored. }\end{array}$ \\
\hline $\begin{array}{l}\text { Dominican } \\
\text { Republic }\end{array}$ & 2001 & $83.81 \%$ & No. \\
\hline Ecuador & 2001 & $22.96 \%$ & $\begin{array}{l}\text { System implementation pending legal } \\
\text { decision on constitutional grounds. }\end{array}$ \\
\hline Latvia & 2001 & $57.53 \%$ & $\begin{array}{l}\text { All workers born after July 1st } 1971 \text { must } \\
\text { participate in new system. Participation is } \\
\text { voluntary for older workers. }\end{array}$ \\
\hline $\begin{array}{l}\text { Russian } \\
\text { Federation }\end{array}$ & 2001 & $26.71 \%$ & $\begin{array}{l}\text { All workers born after } 1966 \text { must participate } \\
\text { in new system. }\end{array}$ \\
\hline Estonia & 2002 & $55.65 \%$ & $\begin{array}{l}\text { All workers born after } 1982 \text { must participate } \\
\text { in the new system. }\end{array}$ \\
\hline Lithuania & 2003 & $25.99 \%$ & Yes. \\
\hline Slovakia & 2003 & $39.68 \%$ & $\begin{array}{l}\text { Full implementation in } 2005 \text {. All workers } \\
\text { entering the labor force in } 2005 \text { or later must } \\
\text { participate in the new system. Existing } \\
\text { workers could opt into the new system } \\
\text { before June } 30^{\text {th }} 2006 \text {. }\end{array}$ \\
\hline
\end{tabular}

Source: Authors' model based on rules of each country's pension system as published in Social Security Programs Throughout the World. See Appendix B. Some countries have instituted reforms, but were not modeled or included in the empirical investigation because of lack of other data. Hong Kong is excluded 
because it is not an independent self-governing country. For Denmark, our data refers to the 1998 reform creating "SP 'Special Pension Savings"” Personal Accounts. Our model calculation of the benefits from personal accounts in Denmark includes both the "SP" scheme and the preexisting "ATP 'Ordinary

Supplementary Pension”” employment-related mandatory defined contribution scheme dating back to 1964 .

Figure 1

Size of Reforms Relative to Per-Capita Income at the Time of Reform

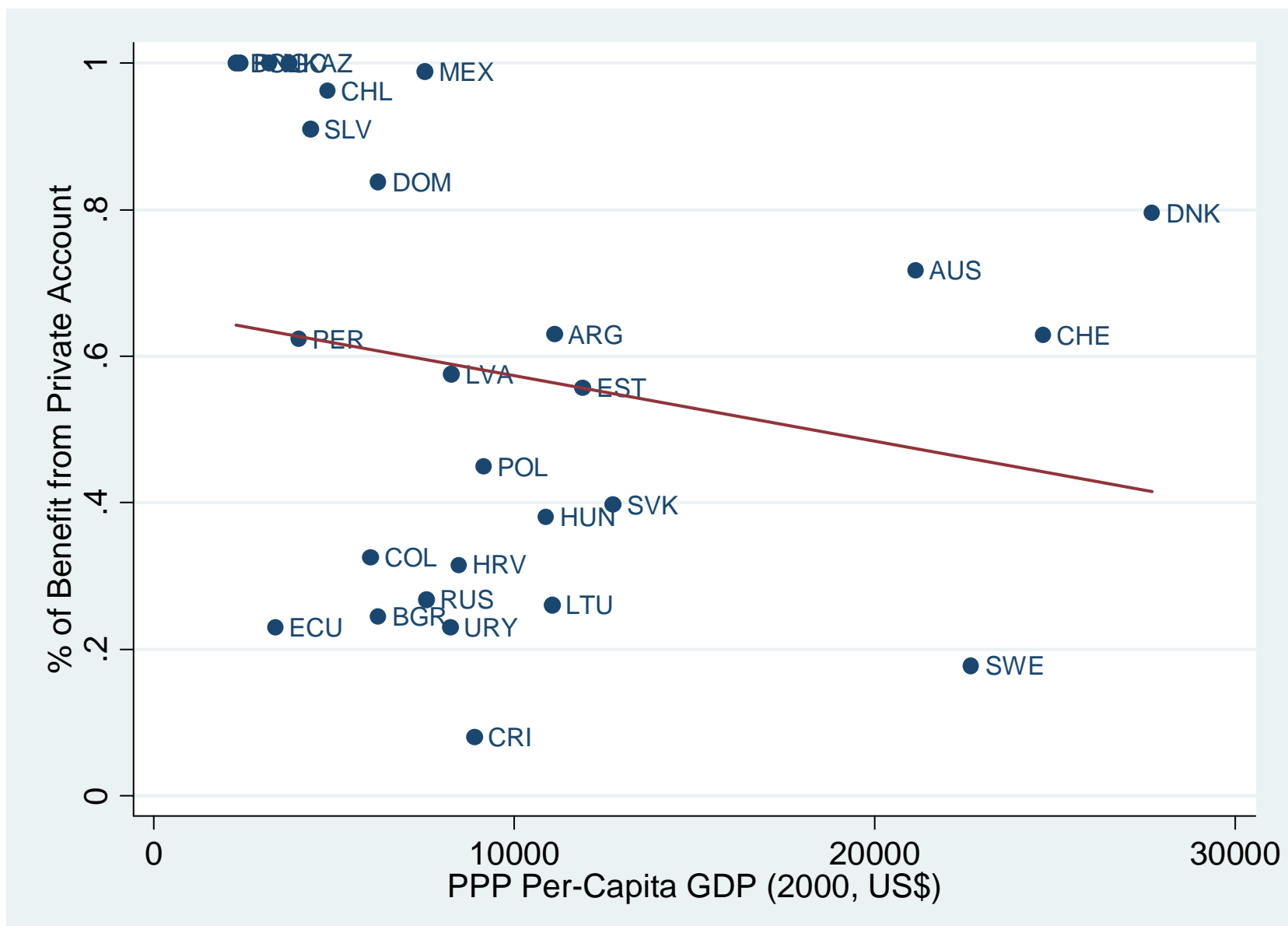

One central theme emerges from our study: the public pension conversions reflect a

fundamental mistrust in the ability of the government to provide secure retirement resources.

The exact nature of the distrust, though, typically differs between reforming countries. 
In more developing countries where reforms have been "fundamental" (i.e., large), the traditional pension systems where often originally created by autocratic regimes who wanted to consolidate power among various stakeholders. As these countries turned more "democratic-like" over time, the will of the "median voter" became more influential. But median voters often lacked or eventually lost trust in the government to run even a basic payas-you-go system that appealed to them. The base system, therefore, is replaced wholesale by personal funded DC accounts that give workers greater transparency and control. While personal accounts can be subject to their own political risks, government interference becomes more obvious. To be sure, the shift toward DC accounts might increase national saving as many of the DB plans were not funded. But a greater level of funding per se is not the primary object of reform itself. Personal accounts would have been created even without demographic concerns. Rather, the increase in personal funding is required to secure a retirement without trusting a pay-as-you-go scheme that only the government can run. ${ }^{5}$

In contrast, in more developed countries where reforms have been "partial" (i.e., smaller), the role of core political instability is less important. Instead, the primary objective is to pre-fund future benefits since many of these countries face severe demographic problems. The government is trusted to run a strict pay-as-you-plan if demographics were stationary. But the government is not trusted to properly save the additional resources that are needed to pre-fund future benefits in the presence of non-stationary demographics. So the creation of personal accounts is a byproduct of attempting to increase funding. If these countries faced no demographic pressures, there would be little incentive to reform.

\footnotetext{
${ }^{5}$ A couple of countries have adopted unfunded 'notional' defined-contribution accounts, sometimes in addition to funded defined-contribution accounts. While a notional account does create a clearer contract with the government, the lack of funding still requires a lot of trust that future governments will fulfill previous promises.
} 
Section 2 of this paper critically analyzes previous attempts to explain conversions to personal accounts. Common rationales include: higher returns; improvements in domestic financial institutional development; improving labor supply and retirement incentives; and hedging demographic changes. In each case, a politically-stable and transparent government could have achieved similar results within the traditional system. The traditional system also tends to have lower transaction costs, less adverse selection, and other costs (Diamond 1996).

Section 3 presents a simple model of a pension system as a game between median voters of successive generations. The model incorporates the potential for a fundamental reform, when inter-generational trust completely breaks down as well as the potential for only a partial reform when additional savings are required to buffer demographic shocks.

We then turn to empirical estimation. Section 4 then presents reduced-form empirical tests on a data panel of reforming and non-reforming countries, across several statistic methods. While we certainly are not the "last word" on measurement in this complicated issue, our evidence seems fairly consistent with our model. Section 5 concludes.

\section{Review of Common Explanations of Reform}

We now critically examine several traditional reasons for pension reform. In each case, we argue that they fail to explain fundamental or even partial reforms.

\subsection{Pursuing Larger Returns}

As traditional public pension systems around the world begin to mature, it is clearer that they provide poor returns. Privatization, it is sometimes argued, can improve returns.

Figure 2 reports the average effective (or "internal”) annualized rates of return earned in the United States Social Security system by generation over time. Effective rates of return 
have declined dramatically over time. The composite average U.S. worker who began to collect a benefit at age 65 in 1941 received a 361/2 percent effective annual rate of return on his pension contributions. In sharp contrast, a person born today into the mature U.S. Social Security system is projected to receive less than a 2 percent effective rate of return.

Figure 2

Effective Real Rates of Returns to the U.S. Public Pension System

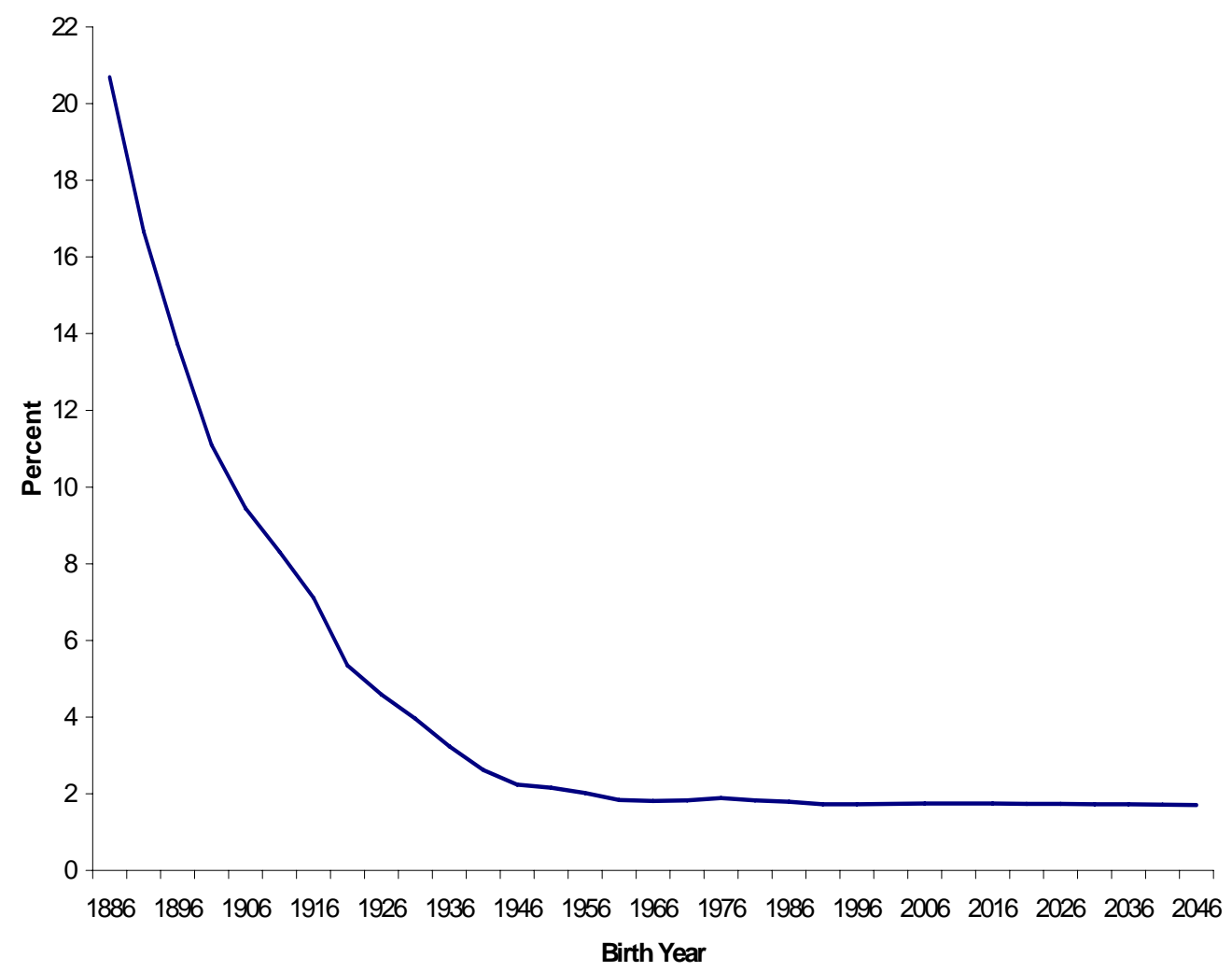

Source: Dean R. Leimer, "Cohort-Specific Measures of Lifetime Net Social Security Transfers," ORS Working Paper No. 59, Social Security Administration, 1994.

But the declining rate of return stems directly from pay-as-you-go financing itself: money flowing into the pension system gets distributed immediately as benefit payments to retirees. Early retirees receive a windfall that is matched in present value by payments made by future generations. Since these windfalls have already been consumed, there is no 
potential for recovering them. ${ }^{6}$ Increased returns only comes from current generations sacrificing some of their consumption today, which they can do without privatization.

\subsection{Improvements in Financial Markets}

Another commonly cited reason for pension reform is to deepen the domestic capital markets. Figure 3 shows the amount of private credit as a share of GDP in several countries before and after pension reform (a hash mark indicates the respective reform dates for reforming countries). Private credit includes the total financial resources provided to the private sector through loans, purchases of non-equity securities, trade credits and other accounts receivable that establish a claim for repayment. Private credit is one of the most commonly used metrics in the literature for indicating an economy's level of financial sophistication, especially for less developed countries in which equity financing is less common. But changes in private credit also reflect the changes in the private savings level following pension reform rather than just changes in financial market institutions. Hence, we also show the private credit levels for several reforming more developed West European countries -- where financial markets were already sophisticated before reform -- in order to better isolate out the commingled saving effects.

Private credit levels in Western European countries are much higher relative to Latin America and Eastern Europe. Even these differences underestimate the greater capital market development in Western European countries where investments tend to be relatively more equity financed. Notice also that private credit indeed expanded in each country following reform -- except for Mexico and Argentina, both of which suffered currency and other financial crises. This evidence would seem to buttress the case for the hypothesis that

\footnotetext{
${ }^{6}$ This zero-sum condition can be traced back to Samuelson (1958) and Diamond (1965) and has been explored
} 
domestic capital market development was a major influence in reform. Many reforming Latin American and Eastern European countries also instituted restrictions that prevented workers from investing their money abroad, also seemingly consistent with this hypothesis.

Figure 3

Private Credit as a Percent of GDP

(Reform dates shown as short vertical lines)

\section{Bolivia, Chile, Colombia, and Peru}

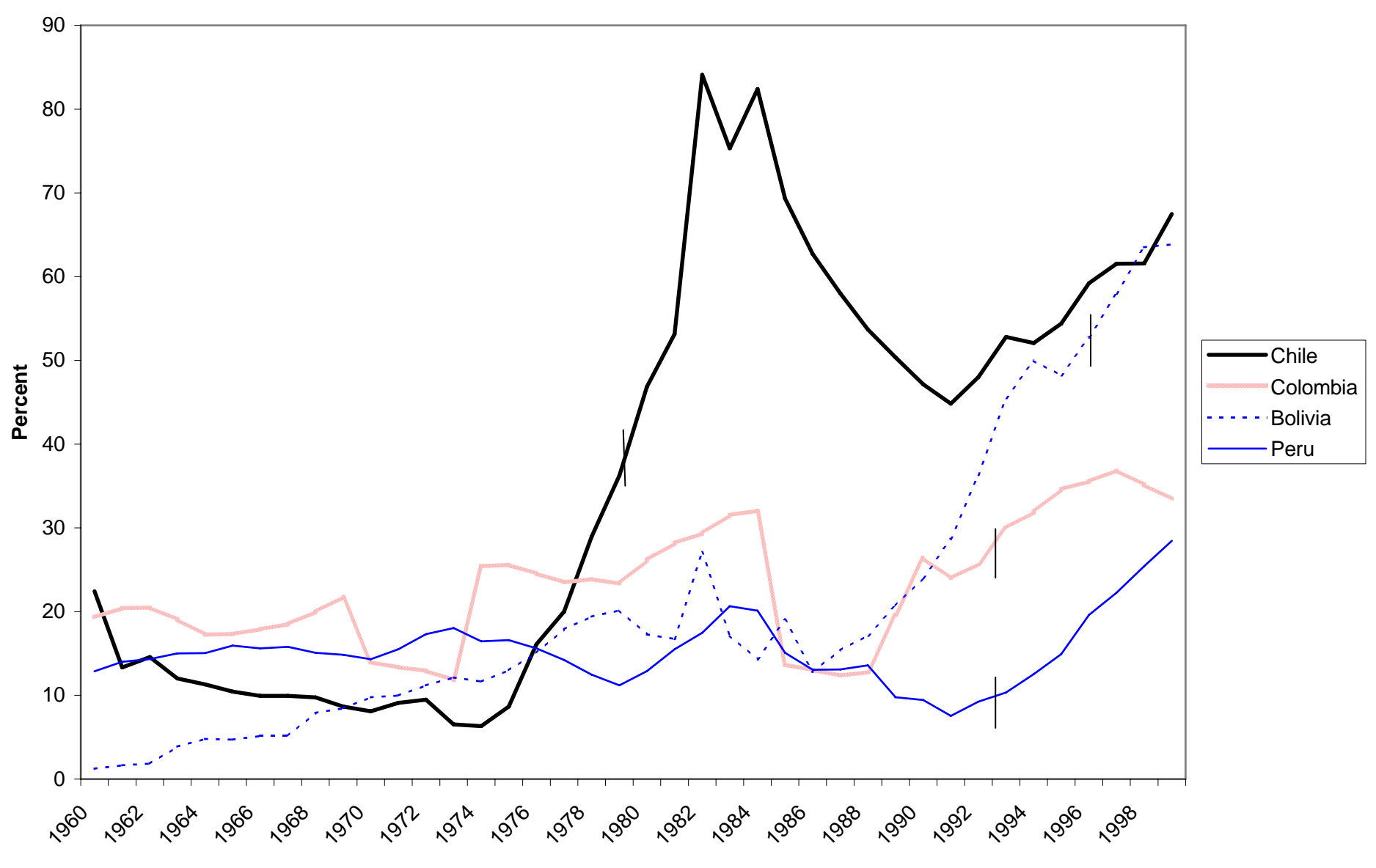

in more detail in Breyer (1989), Geanakopolis, Mitchell, and Zeldes (1999) and Mariger (1999). 
Figure 3 (Continued)

Private Credit as a Percent of GDP

\section{Argentina, El Salvador, Mexico and Uruguay}

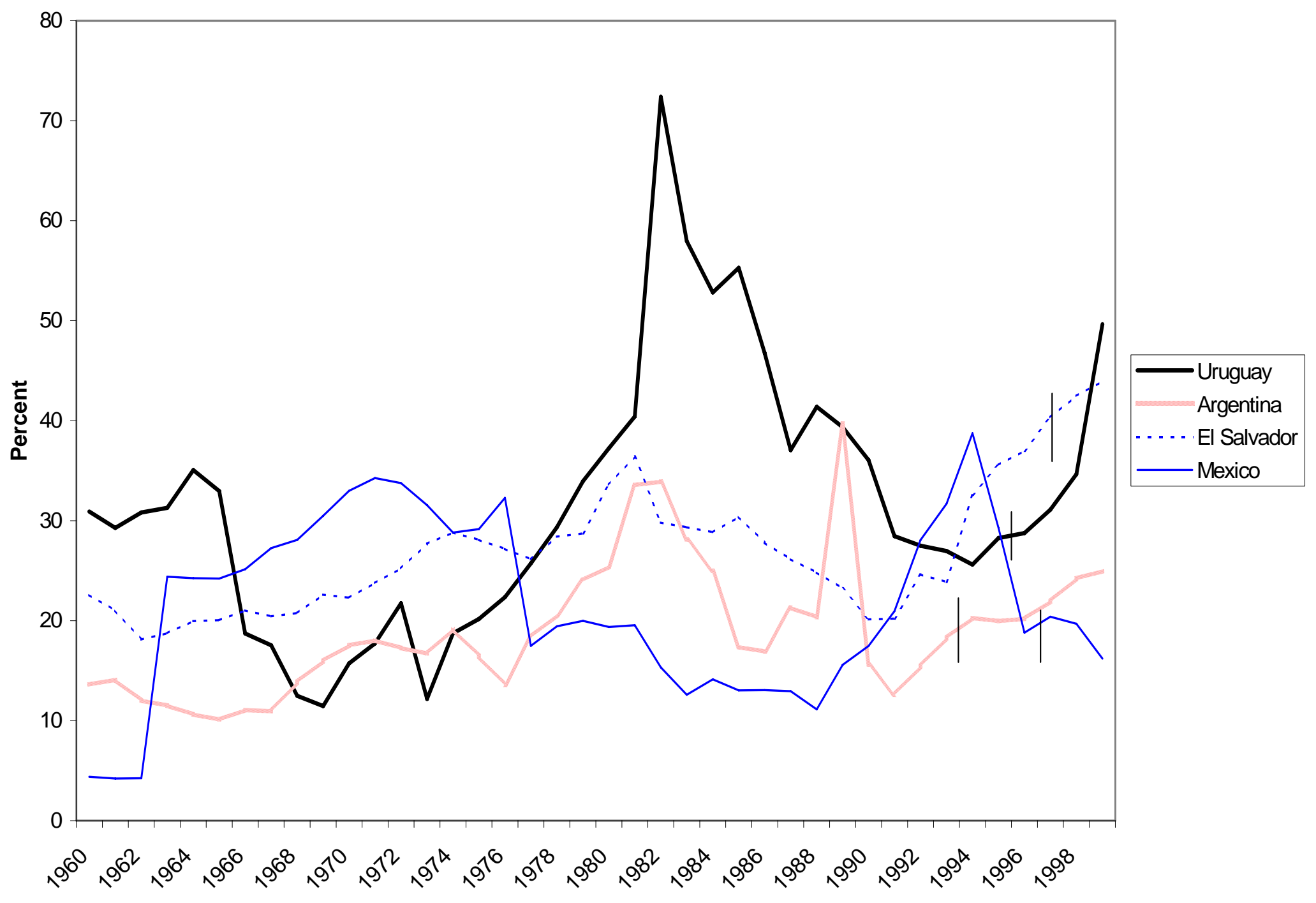


Figure 3 (Continued)

Private Credit as a Percent of GDP

\section{Hungary, Kazakhstan, Poland}

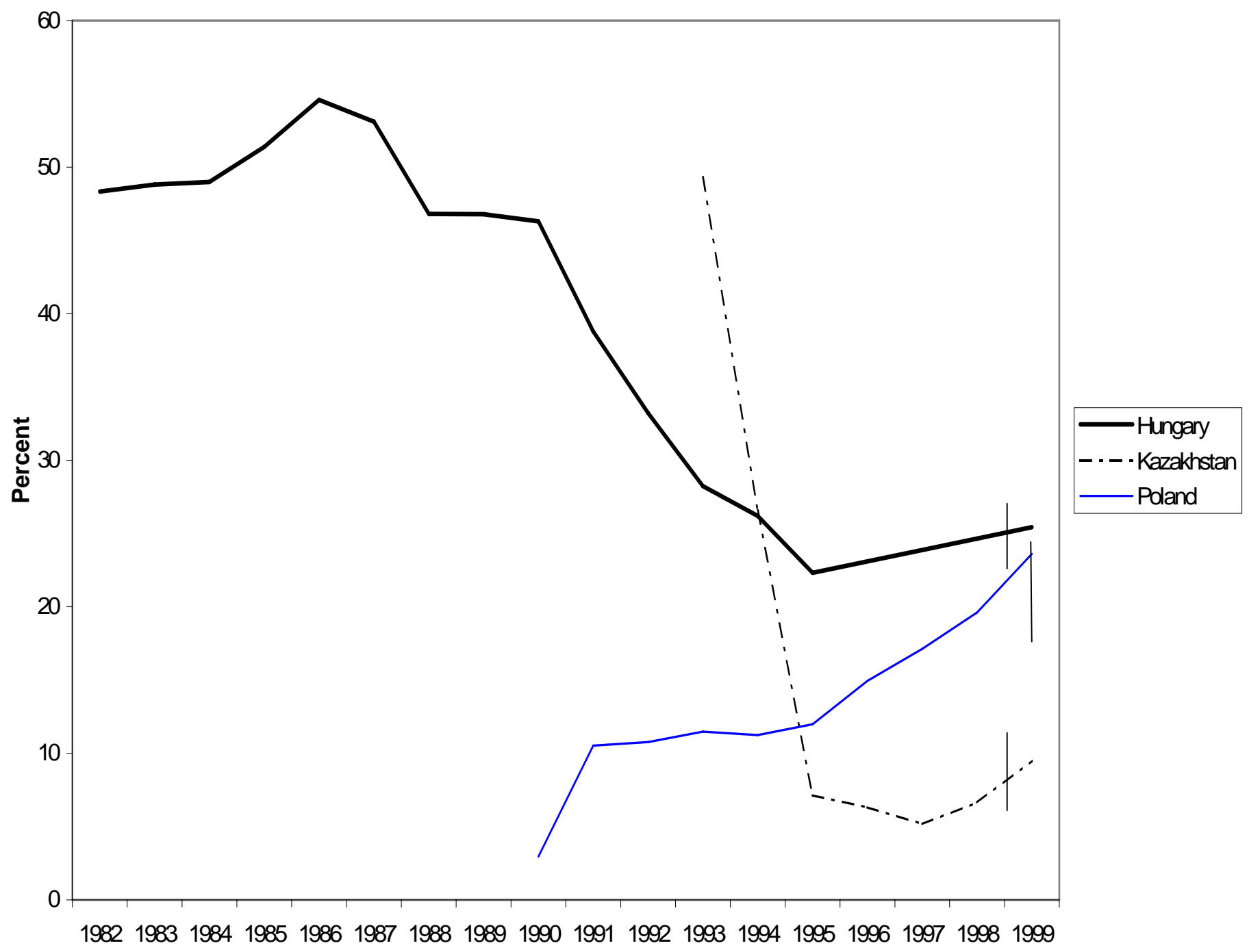


Figure 3 (Continued)

Private Credit as a Percent of GDP

\section{Australia, Sweden, Switzerland, U.K.}

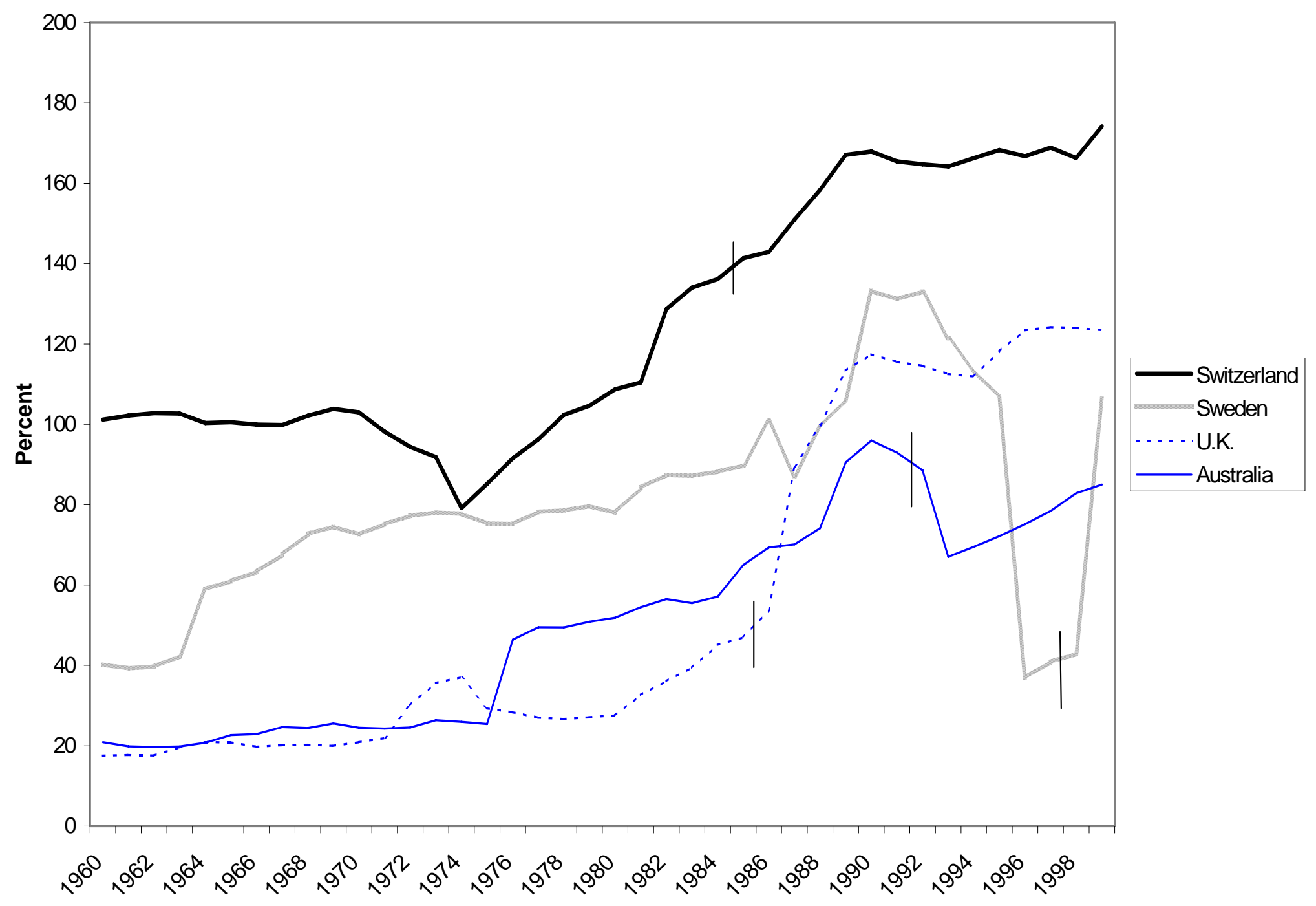


But notice that the post-reform rise in private credit tended to be sharper in Western European countries despite the smaller size of their pension reforms relative to the Latin American and Eastern European nations. Since most Western European countries already had sophisticated financial markets prior to reform, much of their increase presumably stemmed purely from increases in the amount of capital, since pension reforms likely had little impact on the relative reliance on equity financing. This result suggests that the increase in private credit in Latin American and Eastern European nations might also have been driven by the saving effect rather than by direct financial institution development.

Moreover, except Mexico and Argentina, the availability of private credit began to increase in most Latin American and Eastern European countries before the introduction of personal accounts. (Since the personal accounts are unlikely to have a large effect for several years, the effective pre-reform trend is even longer.) Indeed, the introduction of personal accounts does not seem to increase the pre-reform trend in most countries, suggesting that other factors might also be playing an important role in the expansion of private credit.

Pension reforms in developing countries were typically part of larger reforms that spurred capital market development. As discussed by Walker and Lefort (2002), the largest reforms in developing countries include: macroeconomic stability; tax incentives; capital control liberalization; deregulation and competition in the financial services; property rights, bankruptcy legislation and investor protection; and, privatization of state-owned enterprises. When controlling for country-specific factors, Walker and Lefort also find little evidence that pension reform improved financial market development, including the cost of capital, stock market volatility and other measures. Only when other factors are ignored does pension reform seem to have some effect in developing the domestic capital market. Consistently, 
our own more formal empirical estimation (reported in Section 4) provides only weak evidence that public pension reform was motivated by shallow financial markets.

Moreover, personal accounts were not the only way to develop financial institutions. Pre-funding existing traditional public pension systems could, in theory, have also done the job by restricting investments domestically. In fact, using the public pension system to do the “dirty work" would have avoided the appearance of a direct "tax" on workers' investment returns if they were forced to invest domestically within a privatized system. (Some developed countries like Singapore, for example, invest their public pension funds in domestic projects.) In contrast, a home bias in investments has no direct effect on a worker's pension benefit within a traditional system where benefits remain defined by law. Any reduction in returns largely accrues as a hidden actuarial obligation on future generations.

\subsection{Enhancements to Labor Supply}

Payroll taxes in a traditional defined benefit system are distorting for several reasons. First, workers are forced to invest into a pay-as-you-go public pension "asset” that pays a rate of return below what they could have earned in the private sector. Second, redistribution produces larger rates of returns for lower-income workers along with smaller returns for higher-income workers. Third, borrowing constrained workers might not wish to make any contributions at younger ages, even at a market rate of return. Fourth, particular features of the program, such as a spousal benefit, cause additional distortions. Fifth, as documented by Gruber and Wise (1998, eds. 1999), specific rules encourage early retirement.

Private accounts are argued to ameliorate these tax-like disincentives to labor supply. Each of these distortions, however, can be just as easily addressed with the traditional 
pension system with pension reform. Inferior rates of return are a natural outcome of pay-asyou-go financing or redistribution; similarly, tax-induced distortions caused by redistribution are simply the cost of redistribution, which would also exist in a private pension system that maintained the same level of redistribution. ${ }^{7}$ Borrowing constraints could be lessened by starting payroll tax rates at a low level early in life and increasing them with age in order to collect the same present value of income from each worker on average (Hubbard and Judd, 1987). The other distortions are consequences of the rules specific to different public pension systems and can also be addressed within traditional pension systems.

\section{4. $\quad$ Addressing Demographic Changes}

It is also commonly claimed that traditional public pension systems are unable to deal effectively with demographic problems since payroll taxes must increase sharply or benefits decrease sharply as the ratio of retirees to workers increases. In contrast, private accounts should be less vulnerable to demographic changes since retirement benefits are directly tied to previous savings. Demographic concerns, though, are unable to explain reform, at least outside of considerations tied to political trust. Let’s first consider the empirical evidence.

As shown in Table 2, higher-income countries tend to face the largest predicted declines in worker-retiree ratios; but, higher income countries are also those with the smallest pension reforms. In fact, as Figure 4 shows, among actual reforming countries, there appears to be an inverse correlation between demographic problems and the size of actual reform. The direct empirical evidence, therefore, does not seem that supportive at a high level.

\footnotetext{
${ }^{7}$ In fact, actual implementations of privatization actually reduce labor supply distortions. Smetters (2006) derives the neutrality of labor supply to pension reform under the "carve out" scenario; he also demonstrates that "shutdown" reforms actually reduce labor supply incentives.
} 
Table 2

Past and Projected Worker-Retiree Ratios

\begin{tabular}{|c|c|c|c|c|c|c|c|c|c|c|}
\hline & 1995 & 2000 & 2005 & 2010 & 2015 & 2020 & 2025 & 2030 & 2035 & 2040 \\
\hline & \multicolumn{10}{|c|}{ High-Income Countries at time of their Reform } \\
\hline Australia & 3.6 & 3.5 & 3.3 & 2.9 & 2.5 & 2.2 & 1.9 & 1.7 & 1.6 & 1.6 \\
\hline Denmark & 2.9 & 2.9 & 2.6 & 2.3 & 2.1 & 2.0 & 1.8 & 1.6 & 1.5 & 1.5 \\
\hline Hong Kong & 4.2 & 4.3 & 4.2 & 3.5 & 2.8 & 2.0 & 1.5 & 1.3 & 1.2 & 1.1 \\
\hline Sweden & 2.4 & 2.4 & 2.2 & 2.0 & 1.9 & 1.7 & 1.6 & 1.5 & 1.4 & 1.4 \\
\hline Switzerland & 3.0 & 2.9 & 2.6 & 2.3 & 2.1 & 1.8 & 1.5 & 1.3 & 1.3 & 1.3 \\
\hline $\begin{array}{l}\text { United } \\
\text { Kingdom }\end{array}$ & 2.6 & 2.6 & 2.5 & 2.3 & 2.1 & 2.0 & 1.7 & 1.6 & 1.5 & 1.5 \\
\hline & \multicolumn{10}{|c|}{ Medium-Income Countries at time of their Reform } \\
\hline Croatia & 2.5 & 2.4 & 2.5 & 2.4 & 2.1 & 1.9 & 1.8 & 1.7 & 1.7 & 1.6 \\
\hline Hungary & 2.8 & 2.9 & 2.8 & 2.6 & 2.3 & 2.1 & 2.1 & 2.0 & 1.8 & 1.6 \\
\hline Poland & 3.4 & 3.4 & 3.6 & 3.2 & 2.7 & 2.2 & 2.1 & 2.1 & 2.0 & 1.8 \\
\hline Uruguay & 2.9 & 3.0 & 3.1 & 3.1 & 3.0 & 2.8 & 2.6 & 2.5 & 2.3 & 2.1 \\
\hline & \multicolumn{10}{|c|}{ Poorer Countries at time of their Reform } \\
\hline Argentina & 3.7 & 3.8 & 3.9 & 3.8 & 3.6 & 3.4 & 3.2 & 3.0 & 2.8 & 2.4 \\
\hline Bolivia & 7.2 & 7.2 & 7.4 & 7.4 & 7.2 & 7.0 & 6.6 & 6.1 & 5.4 & 4.8 \\
\hline Chile & 5.5 & 5.2 & 4.8 & 4.4 & 3.9 & 3.3 & 2.8 & 2.5 & 2.3 & 2.2 \\
\hline China & 5.8 & 5.6 & 5.4 & 5.0 & 4.1 & 3.7 & 3.0 & 2.4 & 2.1 & 2.0 \\
\hline Colombia & 6.2 & 6.2 & 6.2 & 6.0 & 5.5 & 4.9 & 4.2 & 3.7 & 3.2 & 2.9 \\
\hline Costa Rica & 6.9 & 6.6 & 6.3 & 5.8 & 5.1 & 4.2 & 3.5 & 3.0 & 2.7 & 2.5 \\
\hline Domenica Rep. & 7.9 & 7.5 & 7.3 & 6.9 & 6.1 & 5.2 & 4.3 & 3.6 & 3.2 & 2.8 \\
\hline Kazakhstan & 5.3 & 4.3 & 4.9 & 4.9 & 4.4 & 3.6 & 3.2 & 3.1 & 3.1 & 2.9 \\
\hline El Salvador & 6.7 & 7.3 & 7.6 & 7.5 & 7.4 & 7.3 & 6.7 & 5.5 & 4.3 & 3.4 \\
\hline Mexico & 7.7 & 7.6 & 7.2 & 6.7 & 5.9 & 5.1 & 4.4 & 3.9 & 3.2 & 2.8 \\
\hline Nicaragua & 8.9 & 9.4 & 9.9 & 9.7 & 8.7 & 7.8 & 6.8 & 5.8 & 4.9 & 4.1 \\
\hline Peru & 7.0 & 7.0 & 7.0 & 6.7 & 6.1 & 5.5 & 4.8 & 4.1 & 3.5 & 3.0 \\
\hline
\end{tabular}

Source: Data provided by Robert Palacios, World Bank. 
Figure 4

Size of Reforms Relative to Projected Population aged 65 and older in 2025

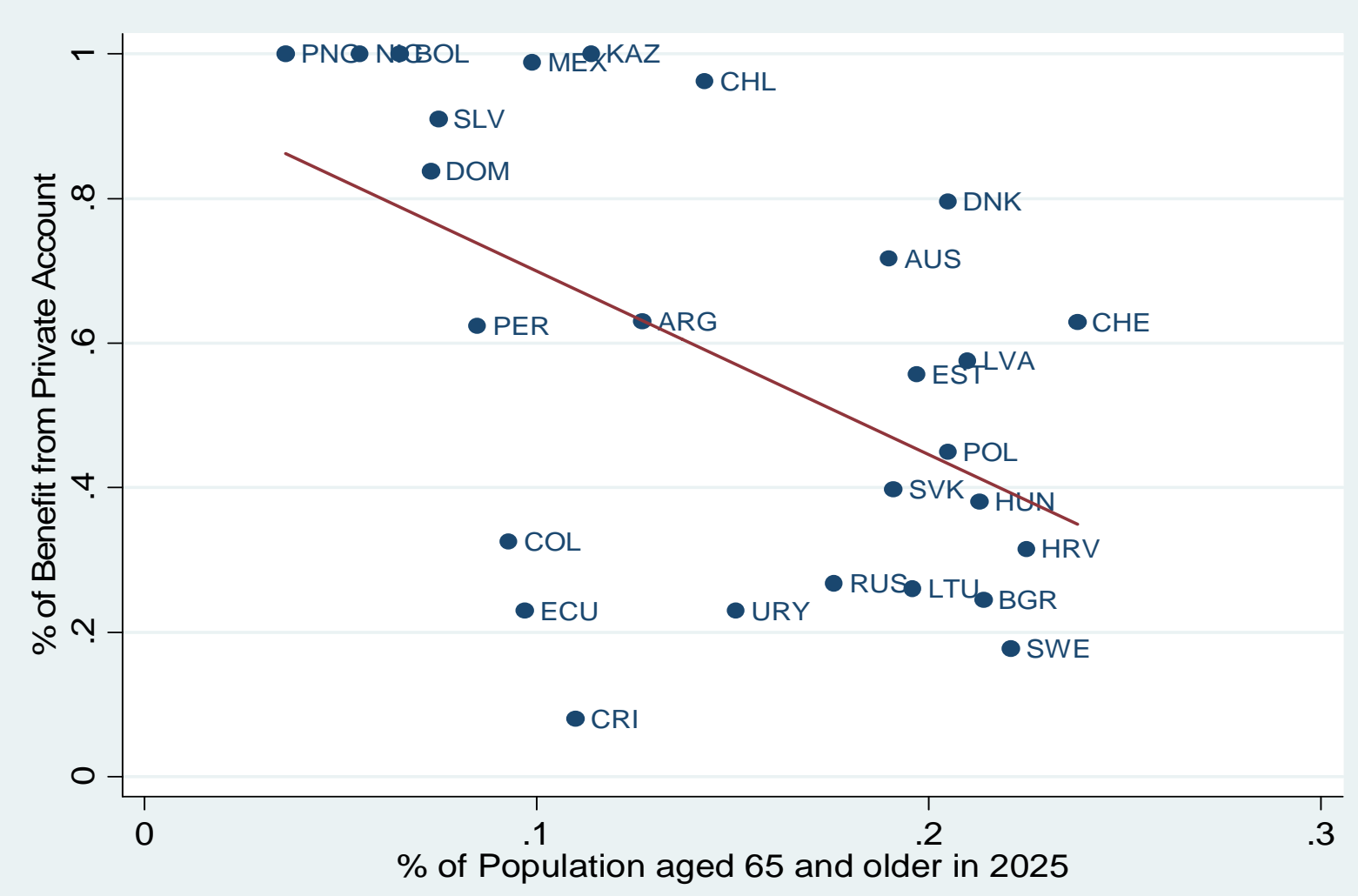

Moreover, in theory, a traditional system could effectively deal with changes in fertility rates by accumulating large reserves when the worker-retiree ratio is large and then spending down the reserves as the ratio decreases. (Since 1983, the United States has been building up its Social Security "trust fund" in an attempt to buffer future costs associated with the retirement of baby boomers.) If these reserves were truly saved, then taxes would remain roughly flat throughout the entire period, as collections would initially exceed costs and then fall below. A personal account system would do no better in hedging demographic risk. However, creating an additional reserve within a traditional pension system requires a level of trust that the money will be saved, a consideration to which we now turn. 


\section{3. $\quad$ A Model of Trust}

We now show how a full breakdown of the inter-generational trust produces large, fundamental pension reform; demographics play little role. However, smaller reforms are motivated by a lack of trust of a different sort: while the government is trusted to run a strict pay-as-you-go system, it might not be trusted to truly save the additional reserves that are required to hedge a demographic shock. Smaller reforms are, therefore, demographic driven.

Consider a simple overlapping-generations model. There are $N_{t}$ first-period agents alive at time $t$. Population at time $t$ grows at rate $n_{t} \equiv N_{t} / N_{t-1}$. The total wage base at time $t$ grows at a gross rate $G_{t} \equiv\left(1+g_{t}\right) \equiv\left(1+n_{t}\right)(1+x)$, where $x$ is the exogenous and constant rate of technological change between time periods. We initially assume that the population is stationary and so we often drop the time subscripts for $N$ and $G$. The gross rate of return to risk-less capital is $R=(1+r)$, where $r$ is the net rate of return. The wage rate at time $t$ is $w_{t}$, which grows at rate $x$, i.e., $w_{t+1}=(1+x) w_{t}$. Factor prices are (trend) stationary, as in a small open economy or with linear technology.

An agent born at time $t$ lives for three periods. The agent has exogenous levels of productivity of $\alpha_{1}$ and $\alpha_{2}$ in the first and second periods, respectively. Productivity in the third period is zero, when he retires. Lifetime utility is given by $\sum_{k=1}^{3} \beta^{k} u\left(c_{k, t}, 1-l_{k, t}\right)$, where: $\beta$ is the growth-adjusted discount rate; $c_{k, t}$ is the level of consumption at age $k$ at time $t$; and, $l_{k, t}$ is the respective level of labor supply, where the total time endowment each period is normalized to unity. The function $u($,) is increasing and concave in both arguments. Lifetime utility is maximized subject to the following budget constraints: 
(1)

$$
\begin{aligned}
& \text { (1) } c_{1, t}+a_{1, t}=\alpha_{1} w_{t} l_{1, t}(1-\tau) \\
& \text { (2) } c_{2, t+1}+a_{2, t+1}=\alpha_{2} w_{t+1} l_{2, t+1}(1-\tau)+R a_{1, t} \\
& \text { (3) } c_{3, t+2}=R a_{2, t+1}+b_{t+2}
\end{aligned}
$$

Variable $a$ represents private assets while $b$ is the social security benefit received in the third period that is financed on a pay-as-you-go basis by a proportional tax $\tau$ on labor earnings.

For expositional simplicity, social security benefits are proportional to previous social security contributions. In the case of stationary demographics, every agent, therefore, earns the same gross "internal" rate of return $G$ on their contributions, equal to the growth rate of the wage tax base. The pay-as-you-go social security benefit received by generation $t$ equals ${ }^{8}$

$$
b_{t+2}=G^{2} \tau \alpha_{1} w_{t} l_{1, t}+G \tau \alpha_{2} w_{t+1} l_{2, t+1}
$$

\subsection{A Theory of Fundamental Reforms: Voting Over Pay-as-you-go Financing}

Suppose that the population growth rate, $n$, is not very large, so that $(1+n)^{2}<(1+n)+1=(2+n)$. Then, the age-2 agent is the median voter that determines whether the policy control of the pay-as-you-go system. Since the median voter is not yet retired, he will vote to continue the system if and only if two conditions are satisfied:

(A) (Incentive Compatible) $\tau \alpha_{2} w_{t+1} l_{2, t+1}<\frac{b_{t+2}}{R}=\frac{G^{2} \tau \alpha_{1} w_{t} l_{1, t}+G \tau \alpha_{2} w_{t+1} l_{2, t+1}}{R}$

(B) (Continuation) The current age-1 agent, generation $t$, votes for $\tau$.

\footnotetext{
${ }^{8}$ I.e., in a stationary economy, equation (4) can be rewritten as the standard pay-as-you-go constraint, $N_{t} b_{t+2}=N_{t+2} \tau \alpha_{1} w_{t+2} l_{1, t+2}+N_{t+1} \tau \alpha_{2} w_{t+2} l_{2, t+2}$.
} 
Condition (A) says that the present value of the future social security benefits that are paid to the median voter must exceed the value of the second-period taxes that he would save today from abandoning the system. Even though pay-as-you-go social security is actuarially unfair to age-1 households in a dynamically efficient economy where $R>G$, age-2 households have already contributed to the system in the previous year. Hence, this incentive compatibility constraint can hold even if social security pays a lower internal rate of return.

Condition (B) is the usual recursive "trigger strategy" belief that enforces cooperation across generations in pay-as-you-go games (Verbon 1988a,b; Kotlikoff, Persson and Svensson 1988; Drazen 2001; Cooley and Soares 1999; Rangel 2003). The current age-2 median voter won't vote to support continuation of the pay-as-you-go system unless the next median voter (who is currently age 1) also supports continuation, ad infinitum. Otherwise, the current median voter would pay into the system but not receive any future benefit. Cooperation is enforced with a simple trigger: Any age-2 agent that abandons the system will be sufficiently punished by reducing his third-period social security benefit by more, in present value, than his second-period tax savings, $\alpha_{2} w_{t+1} l_{2, t+1} \tau$.

Condition (A) is likely to hold in stable economies with a reasonable value of $R$. To see this, suppose that $\alpha_{1}=\alpha_{2}$ (i.e., flat productivity profiles) and $R=1 / \beta$ (i.e., interest rate equals the growth-adjusted rate of time preference). Then condition (A) can be simplified to:

(A') $1<\frac{G}{R}+\frac{G^{2}}{R}=\frac{G+G^{2}}{R}$

The first term $G / R$ in equation (A') corresponds to the tax payments paid in the second period of life and represents the relative rate of return produced by pay-as-you-go financing $G$ relative to the rate $R$ which could have been received in the capital market. In a 
dynamically inefficient economy, $G / R<1$, reflecting the opportunity cost of capital. In other words, the median voter would have been better off if he could have invested his payroll taxes into the capital market. The second term $G^{2} / R$ reflects the fact that the age-2 median voter, however, has already paid into the pay-as-you-go system in the first period, a contribution that would be lost if he votes to abandon the system. The inequality shown in equation (A'), therefore, holds, except for fairly large values of $R>>$ G. In that case, the opportunity cost of the median voter's second-year contribution is large enough that he is willing to forfeit his first-year contribution in order to obtain a larger rate of return.

However, the pay-as-you-go system unravels if the discount rate $R$ effectively becomes too high, potentially in response to uncertainty about the future. Since the "trigger" is recursive, the game collapses if it is not incentive compatible for any future median voter. ${ }^{9}$

Proposition 1. A pay-as-you tax $\tau$ is a Nash, subgame perfect equilibrium if and only if Conditions (A) and (B) hold for current and future median voters. Also, let $\left[0, R_{\max }\right] \in \mathfrak{R}^{+}$be the support over the values of $R$ such that Condition (A) holds. $R_{\max }$ is bounded above.

So we arrive at a theory for large social security reforms: the system unravels if a current or future median voter faces a large enough value of $R$, which effectively causes them to highly discount the value of future social security benefits. Proposition 1 shows that such a value of $R$ exists for any size of the pay-as-you-go system, $\tau$.

Remark 1. Condition (A) can be generalized to the case of non-stationary demographics as: 
(A') $\quad \alpha_{2} w_{t+1} l_{2, t+1} \tau<\frac{G_{t+1} G_{t+2} \tau \alpha_{1} w_{t} l_{1, t}+G_{t+2} \tau \alpha_{2} w_{t+1} l_{2, t+1}}{R}$

Even with substantial deviations from stationary demographics (e.g., a "baby boomer bulge.”), the median voter is age-2 and Condition (A’') holds. To see the latter result, again suppose that $\alpha_{1}=\alpha_{2}$ and $R=1 / \beta$. Condition (A', ) is simplified to $1<\frac{G_{t+2}}{R}+\frac{G_{t+1} G_{t+2}}{R}$. With (trend) stationary factor prices, a demographic bulge, as witnessed in many developed countries, implies $G_{t+1}>G_{t+2}>0 .{ }^{10}$ For some parameter values, the new maximum support value of $R, R_{\max }^{\prime \prime}$, might actually be larger than the support, $R_{\max }$, with stationary demographics; for some parameter values, it is smaller. In either case, the prevalence of nonstationary demographics does not play an important role in undermining the trigger.

\subsection{An Extension to Partial Reforms: Including a Social Security "Reserve”}

The knife-edge nature of the trigger strategy used in Proposition 1, however, rules out an explanation of partial reforms. Moreover, as explained in Remark 1, demographics alone do not play a large role in explaining a collapse of intergenerational cooperation. So why then do some countries reform but not completely abandon their social security systems?

Consider now a dual fiscal policy space in which votes are also cast over an additional proportional payroll tax, $\tau^{a}$, which might be interpreted as being used to fund a social security “reserve.” A direct majority (median voter) model also determines the level of this payroll tax. ${ }^{11}$ If cohort $t$ 's own future social security benefit is then increased by

\footnotetext{
${ }^{9}$ It can be shown that social security will continue provided that the probability of future collapse is not too large. This type of result is fairly standard in dynamic reputation games.

${ }^{10}$ While $n<0$ is possible, $G>0$ since $n>-1$ for any population to remain.

${ }^{11}$ Alternatively, both issues could be voted upon as a bundle, as in a representative democracy model. The solution that we derive extends to this case as well, with some fairly minor modifications.
} 
$R^{2} \tau^{a} \alpha_{1} w_{t} l_{1, t}+R \tau^{a} \alpha_{2} w_{t+1} l_{2, t+1}$ then $\tau^{a}$ represents a pure "funded" portion of social security. ${ }^{12}$

Assuming that borrowing constraints are not binding, such a payroll tax, however, has no impact on any household's budget constraint; it just substitutes public saving for private. A “partial privatization” that simply undoes this payroll tax, $\tau^{a}$, is economically neutral.

Suppose instead that the government contemporaneously redistributes $\tau^{a}$ instead of saving it. Of course, a majority of voters might want redistribution for the usual reasons. But our motivation in this setting is more practical: few people understand government budgetary arithmetic. This revenue might, therefore, naturally be viewed as a part of general pool that is up for grabs -- as enforced by standard accounting practices, including the "unified deficit," which is the headline measure reported in the U.S. But the nation does not literally need to adopt reserve type of budget labels. We now show that non-stationary demographics can generate apparent partial privatization simply based on how majority power shifts over time.

To avoid Condorcet type of cycles, we need to consider voting over a specific redistribution function. ${ }^{13}$ For simplicity, consider voting over a policy rule that distributes these resources as a subsidy across the population on a constant per-capita (per vote) basis. Alternative policy rules could be considered as well; the current rule simplifies the analysis.

Assume that labor supply is inelastically supplied at one unit. ${ }^{14}$ Let $s_{t}$ denote the percapita subsidy at time $t$, in the form of a rebate to each worker:

$$
S_{t}=\frac{N_{t-1} \tau^{a} \alpha_{2} w_{t}+N_{t} \tau^{a} \alpha_{1} w_{t}}{N_{t-2}+N_{t-1}+N_{t}}
$$

\footnotetext{
${ }^{12}$ More technically, we require that, when $\tau^{a}$ is implement, benefits are not increase on the current age-3 retirees. Current age- 2 households then see their third-period benefit increase to $R \tau^{a} \alpha_{2} w_{t+1} l_{2, t+1}$.

${ }^{13}$ This same issue arises with most fiscal policies: for example, we previously considered voting over a fixed form of redistribution from workers to retirees. Voting over exogenous fiscal policy functions is commonly assumed in the literature to avoid Condorcet types of voting indeterminacies.
} 
The numerator in equation (5) equals the additional tax revenue collected from workers at time $t$. The denominator is equal to the size of the population, including retirees at time $t$ $\left(N_{t-2}\right)$, age-2 workers $\left(N_{t-1}\right)$, and age-1 workers $\left(N_{t}\right)$. Workers who are age 1 at time $t$ will vote for this subsidy in a one-shot static game (we extend to a dynamic game below) if (C1) $s_{t}>\tau^{a} \alpha_{1} w_{t}$.

In words, the value of the subsidy must exceed the taxes paid by the additional tax. Similarly, workers who are age 2 at time $t$ will vote for it if:

(C2) $s_{t}>\tau^{a} \alpha_{2} w_{t}$.

Since factor prices are fixed, retirees will always vote for the subsidy, i.e.,

(C3) $s_{t}>0$.

With some algebraic substitution, Conditions (C1) and (C2) can be reduced to:

(C1') $\frac{\alpha_{2}}{\alpha_{1}} N_{t-1}>N_{t-1}+N_{t-2} \Rightarrow \frac{\alpha_{2}}{\alpha_{1}}>1+\left(1+n_{t-1}\right)^{-1}$

(C2') $\frac{\alpha_{1}}{\alpha_{2}} N_{t}>N_{t}+N_{t-2} \Rightarrow \frac{\alpha_{1}}{\alpha_{2}}>1+\left(1+n_{t}\right)^{-1}\left(1+n_{t-1}\right)^{-1}$

In words, (C1'), for example, says that age-1 workers at time $t$ are more willing to support the social security reserve if age-2 workers, whom are also in the tax base, are sufficiently more productive than age- 1 workers, adjusted by the other population competing for the transfer. Intuitively, given the simple per-capita rebate subsidy rule, age-1 households want to effectively "pool" their reserves with more productive age-2 workers, provided that there are not too many other competing voters, $N_{t-1}+N_{t-2}$, participating in the subsidy.

\footnotetext{
${ }^{14}$ The tax-subsidy distorts labor supply, which we want to abstract from for the sake of simplicity.
} 
Lemma 1. (i) With non-negative population growth $\left(n_{t} \geq 0\right)$, age-1 and age-2 workers at time $t$ won't both support a social security reserve, $\tau^{a}$. (ii) The converse is not true: there is a non-empty set of parameters, $\left\{\alpha_{1}, \alpha_{2}, N_{t-1}, N_{t}, N_{t+1}\right\}$, where both workers reject a reserve.

To prove part (i) of Lemma 1, insert (C1') into (C2') to get $\left[1+\left(1+n_{t-1}\right)^{-1}\right]^{-1}>1+\left(1+n_{t}\right)^{-1}\left(1+n_{t-1}\right)^{-1}$, which is a contradiction in the presence of a nonnegative population growth $\left(n_{t} \geq 0\right)$. However, the converse is not true: workers of both ages can vote to reject a reserve. ${ }^{15}$ Intuitively, redistribution between age- 1 and age-2 workers is not zero-sum since age-3 retirees receive transfers but don’t face payroll taxes. Hence, only one age-cohort of workers (age-1 or age-2) could be better off, not both. However, if the transfer to age-3 retirees is large enough, then both age-cohorts could be worse off.

With non-negative trend stationary demographics (where $n_{t}=n \geq 0$ ), a reserve will either always exist or not; a reversal of policy cannot occur. ${ }^{16}$ To see why, consider first the case where age-1 workers favor the reserve. By Lemma 1 (i), age-2 workers will oppose:

$$
\begin{aligned}
& \frac{\alpha_{2}}{\alpha_{1}}>1+(1+n)^{-1} \\
& \frac{\alpha_{1}}{\alpha_{2}}<1+(1+n)^{-2}
\end{aligned}
$$

Aged-3 retirees, of course, still favor the reserve since it is redistributed. Combining their votes with age- 1 households will produce a winning coalition in favor of the reserve since

\footnotetext{
${ }^{15}$ For example, both aged workers will vote against a reserve for the following parameter combination: $\alpha_{1}=1.25, \alpha_{2}=1.75$, and $N_{t}=N_{t-1}=N_{t-2}$

${ }^{16}$ Technically, we only require $n_{t}=n \geq-1 / 2$.
} 
$1<(1-n)+(1+n)=2$. Now, consider the case where age- 1 households oppose the reserve and age-2 workers favor it (i.e., the opposite signs in equations (6) and (7)). If $n<1 / 2$ then the winning coalition always favors the reserve since $1+n<1+(1-n)$; if $n>1 / 2$ then age- 1 workers are plentiful enough to always vote down the reserve. Finally, by Lemma 1 (ii), both aged workers can also reject a social security reserve under the right parameter combination (e.g., $\alpha_{1}=1.25, \alpha_{2}=1.75 ; n=0$ ), i.e., reverse the sign of the inequality shown in equation (6). In particular, they always create a winning coalition that rejects the reserve since $1-n<1+(1+n)$ when $n \geq 0>-1 / 2$. We summarize as follows:

Proposition 2. (i) With non-negative trend stationary demographics $\left(n_{t}=n \geq 0\right)$, a policy reversal of social security reserving (i.e., $\tau_{t}^{a}>0 ; \tau_{t+1}^{a}=0=0$ ) cannot occur. (ii) However, with non-stationary demographics, there exists a non-empty parameter set in which social security reserving is eventually reversed, i.e., "partial privatization.”

We have already proven part (i) of Proposition 2. We only need one example to prove Part (ii) under the fairly plausible restriction $n_{t} \geq 0$, i.e., non-negative population growth. ${ }^{17}$

Example 1. Fix $\alpha_{1}=1.25$ and $\alpha_{2}=1.75$. To reduce notation, set $\tau_{t}^{a}=1=w_{t}$. Hence, an age- $j$ agent will support a social security reserve at time $t, \tau^{a}$, if $s_{t}>\alpha_{j}$. Consider the following sequence of cohort sizes: $\{30,100,200,400,450,500\}$. In other words, sharp increases in cohort sizes are followed by much smaller growth rates, near trend stationary: 
Table 3

\begin{tabular}{|c|c|c|c|c|c|c|c|c|}
\hline & \multicolumn{2}{|c|}{ Age 1} & \multicolumn{2}{|c|}{ Age 2} & \multicolumn{2}{|c|}{ Age 3} & \multirow{2}{*}{$\begin{array}{l}\text { Subsidy } \\
S_{t}\end{array}$} & \multirow{2}{*}{$\begin{array}{l}\text { Votes For (+) } \\
\text { or Against (-) }\end{array}$} \\
\hline Time & $\alpha_{1}$ & $N_{1}$ & $\alpha_{2}$ & $N_{2}$ & $\alpha_{3}$ & $N_{3}$ & & \\
\hline$T$ & 1.25 & 200 & 1.75 & 100 & 0.0 & 30 & 1.29 & +130 \\
\hline$t+1$ & 1.25 & 400 & 1.75 & 200 & 0.0 & 100 & 1.21 & -500 \\
\hline$t+2$ & 1.25 & 450 & 1.75 & 400 & 0.0 & 200 & 1.20 & -650 \\
\hline$t+2$ & 1.25 & 500 & 1.75 & 450 & 0.0 & 400 & 1.04 & -550 \\
\hline
\end{tabular}

A reserve is established (by +130 votes) at time $t$ in face of a large demographic transition, where the worker-to-retiree ratio is 10 . As the population ages, the worker-to-retiree ratio declines to 5 by time $t+1$, and the additional social security reserving is reversed (by 500 votes). Over the longer-term, the worker-to-retiree ratio settles a little above 2; the additional social security reserves are not reintroduced.

In other words, our simple model explains why a reserve is initially created in the presence of a forthcoming "baby boomer” type of demographic shock, eventually undone, and never re-established. A "partial privatization" occurs and is driven by undoing the redistribution of the additional payroll tax, $\tau^{a}$. As noted earlier, if the government were able to actually save the reserve rather than redistribute it, then the policy would simply be mimicking private saving behavior and would be economically neutral (i.e., Ricardian-like).

Importantly, the reversal of the reserve ("partial privatization”) does not need to produce fundamental reform (“full privatization”). Specifically, there is a value of $R$ such that Conditions (A) and (B) still hold after a reversal of the reserve, thereby supporting the continuation of the pure pay-as-you-go system. In particular, it is easy to construct examples where the base pay-as-you-go $\tau$ can be supported by a trigger strategy (Conditions (A) and

17 Part (ii) holds under an even larger parameter space if population growth is not non-negative. 
(B) hold) while an additional social security reserve $\tau^{a}$ is created and then reversed. (In Example 1, set $R=1.9$.) This result is generally consistent with Rangel (2003) who shows that a "Backward Intergenerational Good" can be supported on its own as a trigger strategy whereas a "Forward Intergenerational Good” cannot be supported on its own. ${ }^{18}$

Proposition 3. (i) With trend stationary demographics, Conditions (A) and (B) can hold (pay-as-you-go financing) with or without additional social security reserves. (ii) With nonstationary demographics, a reversal of the additional social security reserving ("partial privatization”) can occur even if pay-as-you-go finance remains (no “full privatization”).

\subsection{Summary}

Our simple median voter model predicts that fundamental reforms to a public pension system ("full privatizations”) are motivated by political and economic turbulences that increase the effective discount rate, thereby undermining the inter-generational trust that is required to enforce continuation of the traditional public pension system. Demographic changes play very little role in motivating large reforms. However, smaller reforms ("partial privatizations”) are more motivated by demographic concerns and are smaller in magnitude since some fundamental inter-generational trust might still remain; the government is simply not trusted to hold additional reserves against demographic changes. We now turn toward investigating these predictions empirically.

\footnotetext{
${ }^{18}$ Rangel shows that a FIG, though, can be supported in equilibrium if bundled together as a single vote with a BIG. In our voting model, allowing for bundled voting (as in a representative democracy) would not affect our key results provided that the range of voting bundles is not restricted. Under the parameter conditions described
} 


\section{Empirical Findings}

Our theoretical model produces two testable hypotheses. First, large reforms are the result of a complete breakdown of the intergenerational game; they are primarily motivated by political and economic turbulence and the associated loss of trust rather than demographic pressure. Second, smaller reforms are more motivated more by demographic pressure rather than a fundamental breakdown of intergenerational trust. This section tests these hypotheses empirically.

\subsection{The Data}

We assembled a comprehensive list of 116 countries throughout the world with current or historic pay-as-you-go systems. ${ }^{19}$ We excluded from our collection 21 countries with provident fund systems. ${ }^{20}$ In addition, a few, mostly smaller, countries with pay-as-yougo systems were excluded due to data constraints. ${ }^{21}$ The specific countries used in the analysis are listed in Appendix A. Of the 116 countries included in our data set, only 26 are reformers. Given the limited size of data, our results should be interpreted as only suggestive.

therein, a representative who favors a bundle of keeping pay-as-you-go financing while abandoning reserving would obtain more votes than a representative who tries to maintain both.

${ }^{19}$ Our primary data source was Social Security Programs Throughout the World, published by the U.S. Social Security Administration and the International Social Security Administration. This publication includes information on almost all countries in the world, but does exclude some countries. Excluded countries consist mostly of developing smaller nations, such as Bhutan and Guinea-Bissau, or countries wracked by conflict, like Afghanistan, Iraq, Somalia, and Eritrea. Other excluded countries simply do not participate in the international community, such as North Korea.

${ }^{20}$ The provident fund countries, many of which are former British colonies such as Singapore, Malaysia, and India, operate a mandatory savings scheme similar in spirit to the private account reforms which are the subject of this paper. However, unlike private account reforms, these provident fund systems typically offer little individual control over investments. All the provident fund systems excluded from our analysis are systems that are the original (often since state declaration of independence) pension systems of the countries concerned.

${ }^{21}$ These are the Bahamas, Belize, Barbados, Cape Verde, Malta, which are small nations for which sufficient reliable data is not available. For Iceland and Luxembourg, we have insufficient political data available from our primary sources because of their small size, although they are advanced economies. Hong Kong's unique political position also excludes it from the analysis. In addition, Cuba, Libya, Liberia, and Uzbekistan are excluded because reliable economic data is unavailable. 
Our dependent (left-hand side) variable in our analysis is the degree of reform, as shown previously in Table 1 . We calculate the annuitized value of private account components, as a percentage of the average retiree's total pension income, based on the published parameters of the pension system. The maximum degree of reform is achieved when $100 \%$ of the average retiree's state pension income is derived from private account sources. Our calculations explicitly model the idiosyncratic features of each country's reform, including state financed minimum pension guarantees and old-age welfare programs, both of which tend to reduce the degree of pension income from private sources, depending on the income distribution in that country. Our actuarial model for each country incorporates that country's income distribution, life expectancy and other key economic and demographic variables. Details of these calculations are in Appendix B. Appendix C explains the variables used in our empirical estimation as well their sources in detail.

To measure the degree of intergenerational 'trust' that is needed to continue a pay-asyou-go system, we examine the amount of historic political instability within a given country. Countries with significant historic political instability, due to concomitant regime changes and systemic upheaval, should possess less inter-generational trust, and are more likely to reform. We constructed an instability index based on data from the Polity IV Project, a widely used panel containing political characteristics of 162 countries from 18002006. Our historic instability index measures the number of times a country had a political regime lasting at least 5 years, since the inception of the state pension system (summarized in Appendix B). This index captures the frequency of regime change, while ignoring extremely short and volatile regimes which would have insufficient time to disrupt existing institutions severely. 
Table 4

Political and Civil Rights

\begin{tabular}{|c|c|c|c|c|c|}
\hline & Year & $\frac{\text { Freedom Inc }}{1 \text { (1:Mo }}$ & $\frac{\text { ex Two Years }}{\text { st Free to 7:Lea }}$ & ore Reform & $\begin{array}{l}\% \text { of Benefit } \\
\text { From }\end{array}$ \\
\hline & Reformed & Political Rights & Civil Liberties & Total Score & Private Account \\
\hline & tries with St & onger Records of & Political and Civ & ights Two Yec & Before Reform \\
\hline Australia & 1992 & 1 & 1 & 1 & 71.69 \\
\hline Denmark & 1998 & 1 & 1 & 1 & 79.54 \\
\hline Sweden & 1998 & 1 & 1 & 1 & 17.73 \\
\hline Switzerland & 1982 & 1 & 1 & 1 & 62.87 \\
\hline United Kingdom & 1986 & 1 & 1 & 1 & n.a. \\
\hline Argentina & 1993 & 1 & 3 & 1.5 & 62.98 \\
\hline Costa Rica & 2000 & 1 & 2 & 1.5 & 7.92 \\
\hline Estonia & 2002 & 1 & 2 & 1.5 & 55.65 \\
\hline Hungary & 1997 & 1 & 2 & 1.5 & 37.96 \\
\hline Latvia & 2001 & 1 & 2 & 1.5 & 57.53 \\
\hline Lithuania & 2003 & 1 & 2 & 1.5 & 25.99 \\
\hline Poland & 1998 & 1 & 2 & 1.5 & 44.96 \\
\hline Slovakia & 2003 & 1 & 2 & 1.5 & 39.68 \\
\hline Uruguay & 1995 & 1 & 2 & 1.5 & 22.96 \\
\hline Bulgaria & 2000 & 2 & 3 & 2.5 & 24.39 \\
\hline Bolivia & 1997 & 2 & 3 & 2.5 & 100.00 \\
\hline Dominican Rep. & 2001 & 2 & 3 & 2.5 & 83.81 \\
\hline Ecuador & 2001 & 2 & 3 & 2.5 & 22.96 \\
\hline Peru & 1991 & 2 & 3 & 2.5 & 62.33 \\
\hline & tries with W & aker Records of $P$ & olitical and Civil & hts Two Year & Before Reform \\
\hline El Salvador & 1996 & 3 & 3 & 3 & 90.97 \\
\hline Nicaragua & 2000 & 3 & 3 & 3 & 100.00 \\
\hline Colombia & 1993 & 3 & 4 & 3.5 & 32.51 \\
\hline Mexico & 1995 & 4 & 3 & 3.5 & 98.87 \\
\hline Croatia & 1999 & 4 & 4 & 4 & 31.48 \\
\hline Russia & 2001 & 4 & 4 & 4 & 26.71 \\
\hline Chile & 1981 & 6 & 5 & 5.5 & 96.25 \\
\hline Kazakhstan & 1998 & 6 & 5 & 5.5 & 100.00 \\
\hline China & 1995 & 7 & 7 & 7 & n.a. \\
\hline
\end{tabular}

Source: Freedom in the World, Freedom House 
However, it is also likely that countries with a longer history of political freedoms are more likely to have the political conditions necessary for the public to express their preferences for reform in the face of instability. Toward that end, we include a measure of "historic democracy" based on the Total Score from the Freedom House index that is popular in the political science literature. Table 4 shows the corresponding values for reforming countries in the year of their reform, although our empirical analysis, of course, includes the values for non-reforming countries as well. To reduce the potential sensitivity of this variable to a single year of data, we take the average of this variable for each country over the last several decades (depending on the amount of data available for each country).

Additional economic and demographic control variables are obtained from the World Bank's World Development Indicators database. We use per-capita GDP, measured in purchasing power parity, as the indicator of the country's wealth level. To control for a country's projected demographic constraints, we include the percentage of the population that is projected to be above 65 in the year 2025, as estimated by the U.N. World Population Prospects database. We also include credit provided by the private sector, scaled by GDP, as a measure of the amount of financial investment and development of the local economy. 
Table 5

Empirical Results

\begin{tabular}{|c|c|c|c|c|c|}
\hline Model & $\begin{array}{c}(1) \\
\text { Probit: } \\
\text { All } \\
\text { Countries } \\
\end{array}$ & $\begin{array}{c}(2) \\
\text { Tobit: } \\
\text { All } \\
\text { Countries } \\
\end{array}$ & $\begin{array}{c}(3) \\
\text { Tobit: } \\
\text { Small } \\
\text { Reformer }\end{array}$ & $\begin{array}{c}(4) \\
\text { Tobit: } \\
\text { Large } \\
\text { Reformers }\end{array}$ & $\begin{array}{c}(5) \\
\text { Tobit: } \\
\text { Large } \\
\text { Reformers } 2^{\#}\end{array}$ \\
\hline Historic Instability & $\begin{array}{c}0.235^{* *} \\
(0.100)\end{array}$ & $\begin{array}{c}0.169 * * \\
(0.083)\end{array}$ & $\begin{array}{l}0.086 * \\
(0.045)\end{array}$ & $\begin{array}{c}0.116 \\
(0.075)\end{array}$ & $\begin{array}{c}0.131 * \\
(0.070)\end{array}$ \\
\hline Projected \% Population 65+ in 2025 & $\begin{array}{c}0.109 * * * \\
(0.031)\end{array}$ & $\begin{array}{c}0.068^{* * *} \\
(0.030)\end{array}$ & $\begin{array}{c}0.064^{* * *} \\
(0.024)\end{array}$ & $\begin{array}{c}0.027 \\
(0.025)\end{array}$ & $\begin{array}{r}0.018 \\
(0.023)\end{array}$ \\
\hline Annual Per Capita PPP GDP $(1,000 s)$ & $\begin{array}{c}-0.057 \\
(0.034)\end{array}$ & $\begin{array}{c}-0.037 \\
(0.031)\end{array}$ & $\begin{array}{c}-0.038 \\
(0.023)\end{array}$ & $\begin{array}{c}-0.018 \\
(0.025)\end{array}$ & $\begin{array}{r}-0.014 \\
(0.022)\end{array}$ \\
\hline \multirow[b]{2}{*}{ Domestic Private Sector Credit (\%GDP) } & $\begin{array}{c}0.083^{* *} \\
(0.035)\end{array}$ & $\begin{array}{l}0.059 * \\
(0.032)\end{array}$ & $\begin{array}{l}0.041 * \\
(0.021)\end{array}$ & $\begin{array}{c}0.035 \\
(0.028)\end{array}$ & $\begin{array}{r}0.035 \\
(0.025)\end{array}$ \\
\hline & $\begin{array}{c}-0.011^{*} \\
(0.005)\end{array}$ & $\begin{array}{c}-0.007 \\
(0.005)\end{array}$ & $\begin{array}{c}-0.004 \\
(0.003)\end{array}$ & $\begin{array}{c}-0.003 \\
(0.004)\end{array}$ & $\begin{array}{r}-0.002 \\
(0.003)\end{array}$ \\
\hline Constant & $\begin{array}{c}-1.653 * * * \\
(0.326)\end{array}$ & $\begin{array}{c}-1.207 * * * \\
(0.401)\end{array}$ & $\begin{array}{c}-0.941 * * * \\
(0.326)\end{array}$ & $\begin{array}{l}-0.437 \\
(0.391)\end{array}$ & $\begin{array}{r}-0.407 \\
(0.366)\end{array}$ \\
\hline $\begin{array}{r}\text { Observations } \\
\text { R-Squared }\end{array}$ & $\begin{array}{c}116 \\
0.231\end{array}$ & $\begin{array}{c}116 \\
0.143\end{array}$ & $\begin{array}{c}102 \\
0.469\end{array}$ & $\begin{array}{c}104 \\
0.090\end{array}$ & $\begin{array}{c}103 \\
0.107\end{array}$ \\
\hline
\end{tabular}

Robust standard errors in parentheses: *** $\mathrm{p}<0.01,{ }^{* *} \mathrm{p}<0.05,{ }^{*} \mathrm{p}<0.1$

\# Includes larger reformers except Kazakhstan 


\subsection{Estimates}

We begin by investigating what motivates the decision to embark on reform itself, regardless of the eventual degree of reform, through the following Probit model:

$$
Y_{i}^{*}=\beta_{0}+\beta_{1} I N S_{i}+\beta_{2} D E M O_{i}+\beta X_{i}+e_{i}
$$

$Y_{i}^{*}$ is the latent variable: $Y=1$ if country $i$ has undergone social security system reform and $Y=0$ otherwise. INS is our constructed measure of historic instability indicating the number of times that country $i$ has undergone a political regime change lasting at least 5 years since the inception of its traditional public pension system. DEMO is the projected proportion of country i's population aged 65 and older in the year 2025. $X$ is a vector of controls for country $i$ consisting of: Purchasing power-adjusted GDP; credit provided to the private sector as a percentage of GDP; and, a measure of historic democratic freedom.

The Probit estimates displayed in Column (1) in Table 5 demonstrate that, as expected, larger degrees of historic instability and greater demographic pressure statistically increase the probability of reform. In relative terms, an increase of one point in the index of historic instability has roughly the same impact as a two percentage point increase in the projected proportion of the population above 65; the marginal effect of the one-point increase in the instability index (not shown) is to increase the probability of reform by 5.4 percentage points, which represents a one-third increase from the base probability of 14.7 percent calculated at the mean of the independent variables. The controls have the expected signs; countries with larger pre-existing private sector capitalization have a lower propensity for reform, while countries with higher values of historic political freedoms are more likely to have the political conditions necessary for the public to express their preferences for reform. Interestingly, per-capita GDP is not statistically significant, thereby suggesting that 
the other factors better explain the variation. The Probit model, though, while a useful first cut, does not give information about the motivation behind the size of reforms.

The Tobit estimator is useful for that purpose:

$$
Y_{i}^{*}=\beta_{0}+\beta_{1} I N S_{i}+\beta_{2} D_{E M O}+\beta X_{i}+e_{i}
$$

$Y_{i}^{*}$ is the latent dependent variable. For values of $Y i^{*}$ above and below the censoring limits of 0 and 1, we observe $Y_{i}$ which is the percentage of pension wealth derived from private account sources on a $0 \%$ to $100 \%$ scale, which describes the extent of reform in country $i$. The independent variables were described above. Column (2) of Table 5 reports the results.

The Tobit estimator shows that an increase in the instability index of one point is associated with an unconditional increase of 16.9 percentage points in pension wealth derived from private account sources. In contrast, the impact of a one percentage-point increase in the projected proportion of the population above 65 is 6.8 percentage points. Thus, the estimated effect of a one point increase in the instability index is roughly two and half times the effect of a one percentage point increase in demographic pressure.

Judging the relative impact of instability versus demographic pressure, though, is not possible based on these coefficients alone because the associated independent variables are not identically normalized. To explore further, the mean value of the instability index is 2.65 for reforming countries with a standard deviation of 1.71 , while the mean value of the projected population above 65 is 15.26 with a standard deviation of 5.94. Assuming linearity in effects, our coefficients therefore suggest that a one standard deviation change in demographic pressures has an approximately $40.53 \%$ greater impact on the extent of reform (conditional on the reform occurring) than a one standard deviation change in the instability index. Still, even these numbers don’t directly test the part of our theory arguing that larger 
reforms are more likely caused by instability than demographics. These magnitudes are also consistent with simply having more countries with smaller reforms (motivated by demographics) in the data relative to countries with larger reforms (motivated by instability).

We, therefore, also report Tobit estimates over restricted ranges of our dependent variable, the size of reform. ${ }^{22}$ Column (3) of Table 5 reports the Tobit results with only smaller reforming nations - those 13 countries in the bottom $50 \%$ of reform size -- included as reformers. The role of demographics for small reformers is now much greater than instability: a one standard deviation change in demographic pressures has a $117 \%$ greater impact on the extent of reform than a one standard deviation change in the instability index.

Column (4) of Table 5 reports the Tobit results with only larger reforming nations those in the top $50 \%$ of reform size -- included. Now, as suspected, the importance of the roles is reversed: a one standard deviation change in the instability index has a $19 \%$ greater impact on the extent of reform than a one standard deviation change in demographic. However, neither statistic is significant at conventional levels (the $p$ value for the instability index is 0.126 ). This insignificance appears to be largely driven by a single outlier country with a large reform despite the presence only one major period of instability: Kazakhstan. In a rush to reform after the fall of communism, this country announced its private pension system plans before its public safety net was formulated. Hence, to be conservative, we coded Kazakhstan as a 100\% reformer even though it has since announced a more traditional public safety net (although the details still remain sketchy). Column (5) of Table 5 shows the effect of dropping Kazakhstan: now instability is significant while the role of demographics remains insignificant for large reformers. Taken at their reported values, a one standard 
deviation change in the instability index has a $99 \%$ greater impact on the extent of reform than a one standard deviation change in demographic pressure.

\subsection{Robustness}

To check the robustness of our results, we first examine the effect of reducing the impact of potential outliers, which is potentially quite important in light of our small dataset. A standard way of examining the impact of outliers is with median regression analysis with iterative weighting. However, our median country is non-reforming (the dependent variable is $0 \%$ ) and so weights cannot be accurately assigned; moreover, this procedure does not respect the censoring at $0 \%$.

Instead, we examine the impact on the Tobit regression of simply dropping the top and bottom $10 \%$ of reforming countries. Comparison of Column (1) of Table 5 and Column (1) of Table 6 shows that the results are basically unchanged, although the importance of instability relative to demographics becomes a little larger.

\footnotetext{
${ }^{22}$ A formal "quantile Tobit" estimator that has been recently developed does not solve for our dataset due to the significant amount of censoring, as most countries are non-reformers. The restricted estimators that we report, therefore, are not full information and are, therefore, not strictly comparable.
} 
Table 6

Robustness Checks

\begin{tabular}{|c|c|c|c|c|c|}
\hline Model & $\begin{array}{c}(1) \\
\text { Tobit: } \\
10 \% \\
\text { Outliers } \\
\text { Removed } \\
\end{array}$ & $\begin{array}{c}(2) \\
\text { Cox } \\
\text { Proportional } \\
\text { Hazards }^{\#}\end{array}$ & $\begin{array}{c}\text { (3) } \\
\text { Tobit: } \\
\text { Latin } \\
\text { America } 1\end{array}$ & $\begin{array}{c}(4) \\
\text { Tobit: } \\
\text { Latin } \\
\text { America } 2\end{array}$ & $\begin{array}{c}(5) \\
\text { Tobit: Large } \\
\text { Reforms } \\
\text { and Latin } \\
\text { America } 2 \\
\end{array}$ \\
\hline Historic Instability & $\begin{array}{c}0.169 * * \\
(0.074)\end{array}$ & $\begin{array}{l}1.251 * * \\
(0.139)\end{array}$ & $\begin{array}{l}-0.150 \\
(0.124)\end{array}$ & $\begin{array}{l}-0.141 \\
(0.125)\end{array}$ & $\begin{array}{l}-0.237 \\
(0.153)\end{array}$ \\
\hline Projected \% Population 65+ in 2025 & $\begin{array}{l}0.066 * * \\
(0.027)\end{array}$ & & $\begin{array}{c}0.093 * * * \\
(0.031)\end{array}$ & $\begin{array}{c}0.118^{* * *} \\
(0.038)\end{array}$ & $\begin{array}{c}0.067 * * \\
(0.032)\end{array}$ \\
\hline Annual Per Capita PPP GDP $(1,000 s)$ & $\begin{array}{l}-0.211 \\
(0.027)\end{array}$ & $\begin{array}{c}0.896 * * \\
(0.043)\end{array}$ & $\begin{array}{l}-0.014 \\
(0.028)\end{array}$ & $\begin{array}{l}-0.005 \\
(0.029)\end{array}$ & $\begin{array}{c}0.005 \\
(0.021)\end{array}$ \\
\hline \multirow[b]{2}{*}{ Domestic Private Sector Credit (\%GDP) } & $\begin{array}{l}0.052 * \\
(0.030)\end{array}$ & & $\begin{array}{c}0.004 \\
(0.033)\end{array}$ & $\begin{array}{l}-0.009 \\
(0.035)\end{array}$ & $\begin{array}{l}-0.016 \\
(0.029)\end{array}$ \\
\hline & $\begin{array}{l}-0.009 * \\
(0.005)\end{array}$ & $\begin{array}{c}0.989 \\
(0.007)\end{array}$ & $\begin{array}{l}-0.009 * \\
(0.004)\end{array}$ & $\begin{array}{l}-0.010 * \\
(0.005)\end{array}$ & $\begin{array}{l}-0.006 \\
(0.004)\end{array}$ \\
\hline \multirow[b]{3}{*}{$\begin{array}{r}\text { Latin America * Projected \% Population } \\
65+\text { in } 2025\end{array}$} & & $\begin{array}{c}1.145^{* * *} \\
(0.054)\end{array}$ & & & \\
\hline & & & $\begin{array}{l}0.299 * \\
(0.163)\end{array}$ & $\begin{array}{c}0.224 \\
(0.156)\end{array}$ & $\begin{array}{c}0.287 \\
(0.177)\end{array}$ \\
\hline & & & $\begin{array}{c}0.032 \\
(0.047)\end{array}$ & $\begin{array}{c}-0.129 * \\
(0.072)\end{array}$ & $\begin{array}{c}-0.080 \\
(0.060)\end{array}$ \\
\hline Latin America & & & & $\begin{array}{c}2.198 * * * \\
(0.817)\end{array}$ & $\begin{array}{c}1.307 * \\
(0.670)\end{array}$ \\
\hline Constant & $\begin{array}{c}-1.301^{* * * *} \\
(0.406)\end{array}$ & & $\begin{array}{c}-1.282 * * * \\
(0.416)\end{array}$ & $\begin{array}{c}-1.833 * * * \\
(0.587)\end{array}$ & $\begin{array}{c}-0.697 \\
(0.512)\end{array}$ \\
\hline $\begin{array}{r}\text { Observations } \\
\text { R-Squared }\end{array}$ & $\begin{array}{c}111 \\
0.220\end{array}$ & & $\begin{array}{c}116 \\
0.236\end{array}$ & $\begin{array}{c}116 \\
0.298\end{array}$ & $\begin{array}{c}104 \\
0.338\end{array}$ \\
\hline
\end{tabular}

Robust standard errors in parentheses: ${ }^{* * *} \mathrm{p}<0.01,{ }^{* *} \mathrm{p}<0.05,{ }^{*} \mathrm{p}<0.1$

\#: Hazard ratios are reported. 
We also estimate a Cox proportional hazard model with time-varying covariates:

$$
\mathrm{H}_{i t}=\beta_{0}+\beta_{1} I N S_{i t}+\beta_{2} D E M O_{i t}+\beta X_{i t}+e_{i}
$$

$\mathrm{H}_{i t}$ is the log of the hazard ratio, the probability of "failure" (reform) at time $t$ for country $i$. Country $i$ is modeled as "failing" in the year $t$ at which that country undergoes pension reform; otherwise, country $i$ is assumed to continue without failure until the year 2003, when our dataset ends. INS is the instability index of country $i$ at time $t$, while DEMO is now the life expectancy in country $i$ at time $t$; we are not able to include the share of the population that is projected to be above age 65 because a time series of historical population projections are not available. The only other control contained in $X$ is the purchasing power GDP in country $i$ at time $t$; our other covariates were not available over the relevant historical period.

An advantage of the Cox specification is its ability to include the actual timing of a reform. The key disadvantage is the required omission of many important control variables. Nonetheless, Column (2) of Table 6 shows that both instability and increases in life expectancy are associated with an increased hazard, or probability, of reform. In terms of relative effects, an increase in our instability index of one unit increases the risk of reform by the same amount as a 1.5 year increase in population life expectancy.

Finally, we test the importance of the "Latin America” effect. Brooks (2007) argues that peer effects are an important factor behind the adoption of pension reforms with other countries following Chile's pioneering reform. Under this view, reforms are transmitted between countries through formal and informal links, which are more pronounced among geographic and cultural peers. 
Table 7

Demographic Pressure, Historic Instability and Degree of Reform

\begin{tabular}{|c|c|c|c|}
\hline Country & $\begin{array}{c}\text { Projected } \\
\text { \% Population 65+ in } \\
2025 \\
\end{array}$ & $\begin{array}{c}\text { Historic } \\
\text { Instability Index }\end{array}$ & Degree of Reform \\
\hline \multicolumn{4}{|c|}{ Latin American Countries } \\
\hline Nicaragua & 5.5 & 2 & $100.00 \%$ \\
\hline Bolivia & 6.5 & 3 & $100.00 \%$ \\
\hline Dominican Republic & 7.3 & 3 & $83.81 \%$ \\
\hline El Salvador & 7.5 & 3 & $90.97 \%$ \\
\hline Peru & 8.5 & 4 & $62.33 \%$ \\
\hline Columbia & 9.3 & 2 & $32.51 \%$ \\
\hline Ecuador & 9.7 & 4 & $22.96 \%$ \\
\hline Mexico & 9.9 & 3 & $98.87 \%$ \\
\hline Costa Rica & 11 & 0 & $7.92 \%$ \\
\hline Argentina & 12.7 & 7 & $62.98 \%$ \\
\hline Chile & 14.3 & 5 & $96.25 \%$ \\
\hline Uruguay & 15.1 & 6 & $22.96 \%$ \\
\hline \multicolumn{4}{|c|}{ Eastern European Countries } \\
\hline Kazakhstan & 11.4 & 1 & $100.00 \%$ \\
\hline Russian Federation & 17.6 & 2 & $26.71 \%$ \\
\hline Slovakia & 19.1 & 4 & $39.68 \%$ \\
\hline Lithuania & 19.6 & 2 & $25.99 \%$ \\
\hline Estonia & 19.7 & 1 & $55.65 \%$ \\
\hline Poland & 20.5 & 3 & $44.96 \%$ \\
\hline Latvia & 21.0 & 3 & $57.53 \%$ \\
\hline Hungary & 21.3 & 3 & $37.96 \%$ \\
\hline Bulgaria & 21.4 & 3 & $24.39 \%$ \\
\hline Croatia & 22.5 & 5 & $31.48 \%$ \\
\hline \multicolumn{4}{|c|}{ Western Europe and Rest of World } \\
\hline Australia & 19 & 0 & $71.69 \%$ \\
\hline Denmark & 20.5 & 2 & $79.54 \%$ \\
\hline Sweden & 22.1 & 1 & $17.73 \%$ \\
\hline Switzerland & 23.8 & 0 & $62.87 \%$ \\
\hline
\end{tabular}

Of course, peer effects are not inconsistent with our model: similar to our "historic democracy" variable, peer effects potentially help enable voters to push for large reforms in the face of instability. Nonetheless, Table 7 reveals a striking pattern. The majority of reforming countries with severe demographic problems are located in Europe and the former 
Eastern Europe, while countries with relatively young populations are mostly in Latin America. By contrast, no such strong pattern is present in the instability index. Significantly, it is largely those countries in Latin America with high instability and relatively young populations, who have undertaken the largest degrees of reform.

Column (3) of Table 6, present results from a modified Tobit model with the interaction terms “Latin America X Historic Instability” and “Latin America X Projected \% Population 65+ in 2025.” The coefficient for the Latin America instability interaction term is large and statistically significant at the $10 \%$ level while the Latin America population interaction term is not. (The previous control for Historic Instability now becomes insignificant and the "wrong” sign.) Hence, instability in "Latin America" is associated with reform whereas demographics in Latin America seem to play a smaller role.

Column (4) of Table 6 then adds a fixed-effects indicator for "Latin America" to allow for a different intercept for Latin America. Since there are just 14 non-Latin American reforming countries and 12 Latin American reformers, this additional control substantially slices the data. So, our empirical results, which should already be interpreted with some caution, become a bit more suspect. With that caveat in mind, we find a strong and highly significant pure "Latin American" intercept effect. This finding has an unclear interpretation with our theoretical model. One on hand, it is consistent with a "general revolution" in Latin America that is occurring independently of demographics, a conjecture consistent with our model. Indeed, notice that the coefficient on the interaction term "Latin America X Projected \% Population 65+ in 2025" (significant at the 10\% level) is now of the "wrong" sign, suggesting that demographics play very little (in fact, a negative) role in Latin American reforms. On the other hand, the strong "Latin American" intercept could reflect other fixed 
factors in Latin America outside of our model. The coefficient on the interaction term "Latin America X Historic Instability" is of the "correct" sign but has a corresponding $p$ value around 15.5, making it significant at the $16 \%$ level, outside of conventional levels.

For additional robustness, Column (5) of Table 6 shows a version of "Large Reformers" reported in Column (4) of Table 5 combined with "Latin America 2" reported in Column (4) of Table 6. The coefficient on the pure "Latin American" intercept is reduced in half (1.31) and is now barely significant at the 5\% level. The interaction of "Latin America X Historic Instability” is now significant at the $10.7 \%$ level, just outside our normal threshold. The demographics interaction term is now insignificant (and still of the "wrong” sign).

\subsection{Why did unstable countries create social security systems in the first place?}

Our analysis is confronted with the following question: why were social security systems, which were eventually fundamentally reformed, created in the first place? The answer appears to lie in the fact that many social security systems did not originate for the median voter's benefit, but rather to help the ruling autocratic regime consolidate power by redistributing resources toward powerful, focused stakeholders. Only over time did more progressive political changes enable the will of the median voter that led to their unraveling.

Indeed, many social security systems started with pension schemes for the military, civil service, and other elites vital to support the perpetuation of an authoritarian regime. In these autocratic regimes, instability provides the impetus to create, and even expand, the social security system in an attempt to shore up political power. As Mesa-Lago argues:

“...social security in Latin America has often been manipulated to gain the electoral support of a particular clientele, to legitimate a spurious political regime, and to satisfy the needs and coopt powerful pressure groups which threaten the status quo”. (Mesa-Lago 1978) 
As documented by Mesa-Lago, early social security regimes in Chile, Uruguay, Peru, Argentina and Mexico were actually highly regressive, non-democratic schemes aimed at redistributing wealth to a narrow political elite including the military and civil service.

We can investigate the authoritative origins of social security systems with our own dataset. Figure 5 shows that among countries that eventually reformed there exists a positive correlation between authoritarianism and political instability at the time of inception of the social security system, indicating that authoritarian regimes did indeed engage in the creation of systems that were highly likely to eventually fail, for the purpose of shoring up political support. In contrast, in Figure 6 there is no such correlation between authoritarianism and political instability at the time of social security program inception among countries that did not eventually reform. 
Figure 5

Degree of Political Freedom and Historic Instability at Time of Social Security System Creation, Reforming Countries Only

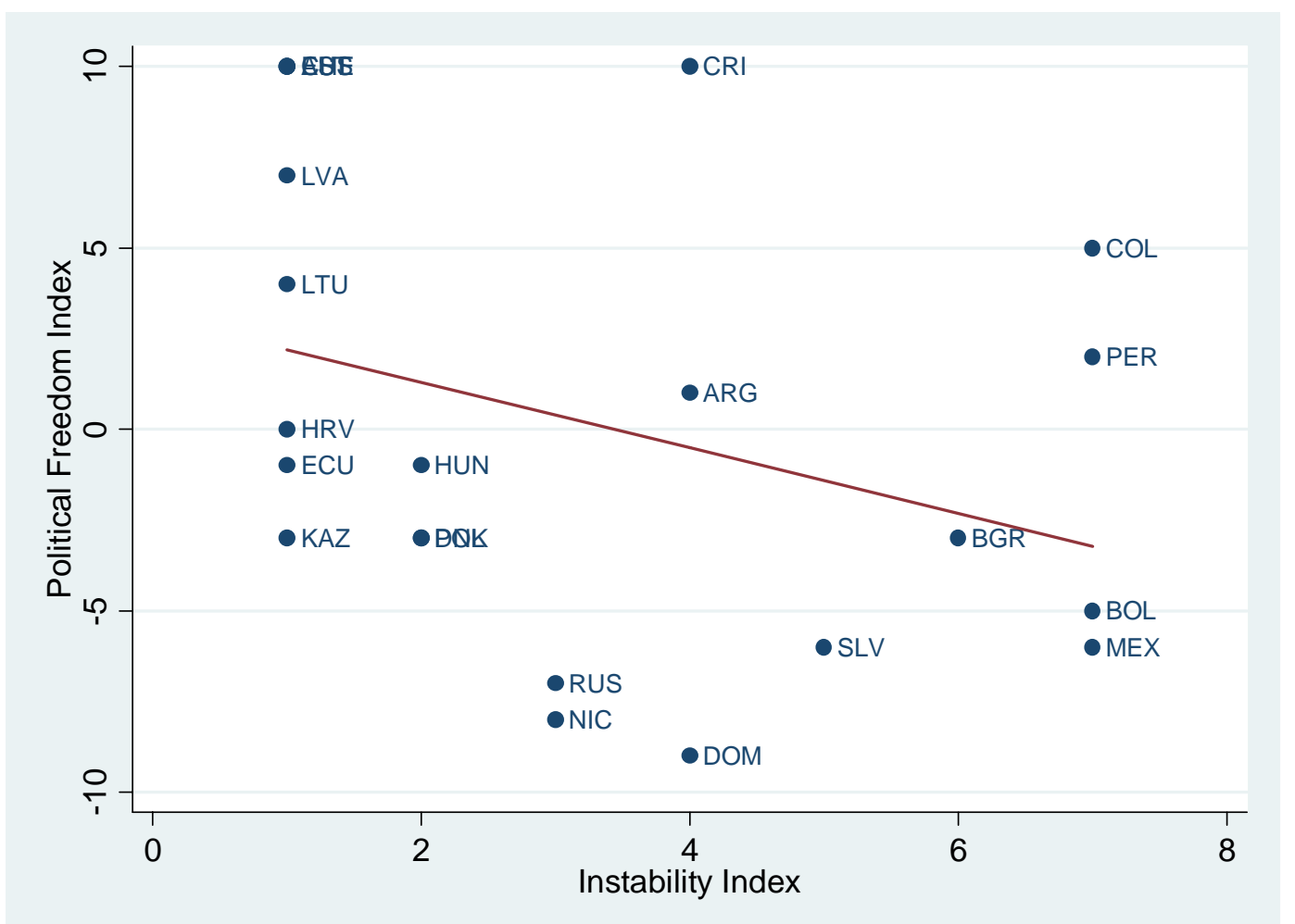

The graph shows a negative relationship between the degree of political freedom at the time of the creation of the social security system, and the degree of instability in that country. For reforming countries, the more unstable the country, the more autocratic the regime that brought the social security system into place. The estimated slope coefficient is -0.903 and the relationship is not statistically significant at conventional levels, with a p-value of 0.126. 
Figure 6

Degree of Political Freedom and Historic Instability at Time of Social Security System Creation, Non-Reforming Countries Only

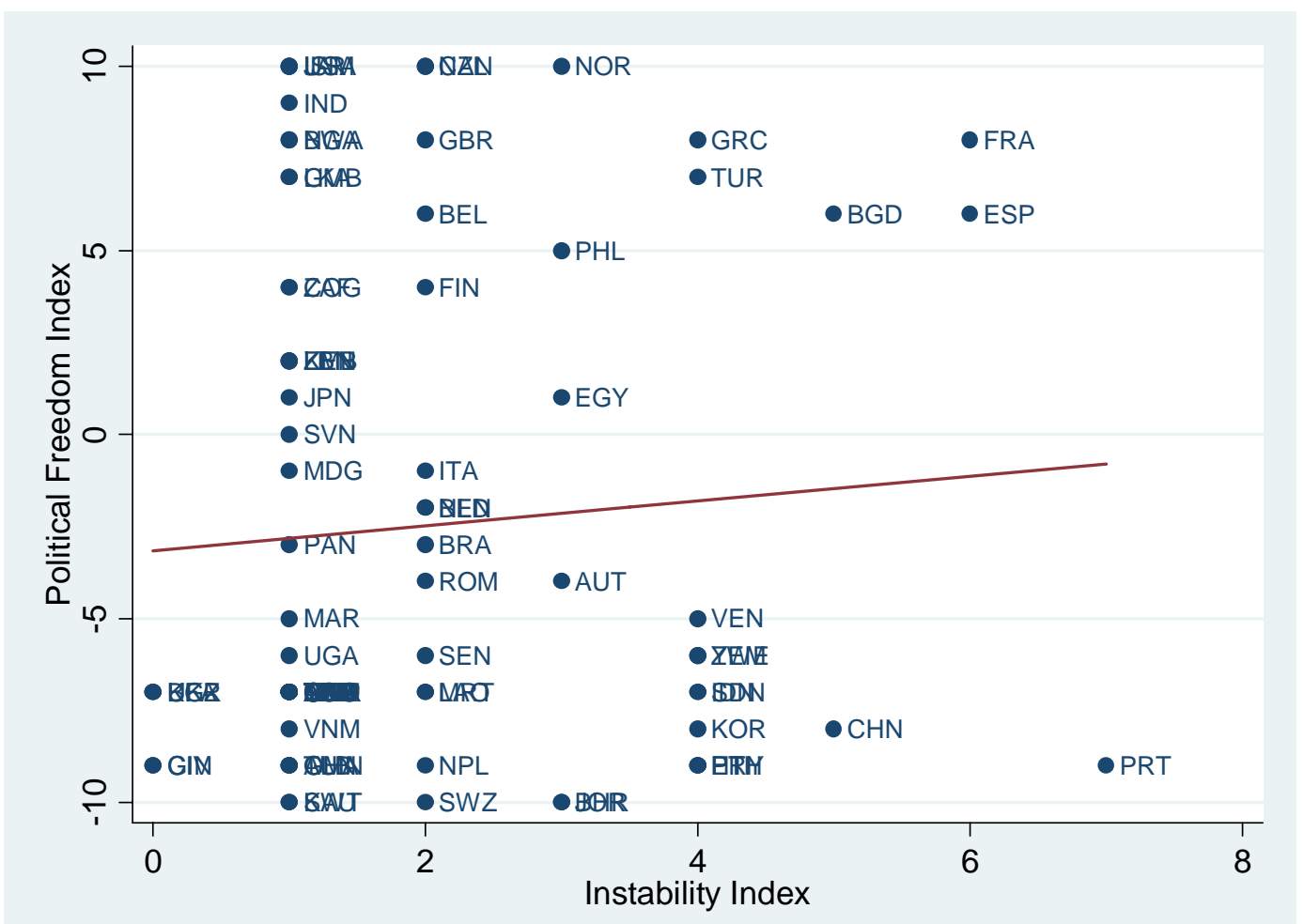

The graph shows a slight positive relationship between the degree of political freedom at the time of the creation of the social security system, and the degree of instability in that country. For non-reforming countries, there appears to be little relationship between the degree of autocracy and the degree of instability at the time of social security system origin. The slope coefficient of the best-fit line is 0.338 and the relationship is not statistically significant, with a p-value of 0.497 .

\section{5. $\quad$ Conclusions}

Fundamental reform of social security systems from traditional pay-as-you-go defined benefit systems toward defined-contribution accounts represents one of the most important fiscal policy changes worldwide during the past century. The motivation for reform has been previously unclear, especially since the traditional pension model possesses favorable characteristics along several meaningful fronts. Even less clear is why these reforms have been larger in developing countries facing less severe demographic problems. We propose a simple model of "intergenerational trust" model that is consistent with these 
stylized facts. The model generates fundamental (large) reforms in the face of political instability that are largely not demographically driven. Smaller reforms, however, can also emerge, which are mostly driven by demographics. Empirical analysis is provided that seems to support the basic tenets of the model. However, we interpret our evidence with some caution. Ethnographic country case studies could provide useful complementary analysis in the future.

\section{References}

Altig, David E., Alan J. Auerbach, Laurence J. Kotlikoff, Kent A. Smetters, and Jan Walliser. "Simulating Fundamental Tax Reform in the United States." American Economic Review, 91(3), 2001: 574-595

Baldwin, Richard E. "Measurable Dynamic Gains From Trade.” Journal of Political Economy, 100(1), 1992: 162-174

Bassetto, Marco. "Political Economy of Taxation in an Overlapping-Generations Economy." Review of Economic Dynamics, 11(1), 2008: 18-43

Breyer, F. "On the Intergenerational Pareto Efficiency on Pay-as-you-go Financed Pension Systems.” Journal of Institutional and Theoretical Economics, 145, 1989: 643-58

Brooks, Sarah M. "Globalization and Pension Reform in Latin America." Latin American Politics and Society, 49(4) 2007: 31-62

Cooley, Thomas F. and Jorge Soares. "A Positive Theory of Social Security Based on Reputation.” Journal of Political Economy, 107(1) 1999: 135-160

Diamond, Peter. "National Debt in a Neoclassical Growth Model." American Economic Review, 55(5:1) 1965: 1126-1150

Diamond, Peter. "Proposals to Restructure Social Security," Journal of Economic Perspectives, 10(3) 1996: 67-88.

Elmendorf, Douglas W. and Louise M. Sheiner. "Should America Save for its Old Age? Fiscal Policy, Population Aging, and National Saving." Journal of Economic Perspectives, 14(3) 2000: 57-74 
Feldstein, Martin. “The Missing Piece in Policy Analysis: Social Security Reform.” The Richard T. Ely Lecture, in American Economic Review, 86(2) 1996: 1 - 14

Feldstein, Martin and Jeffrey Liebman, "Social Security." in Alan J. Auerbach and Martin Feldstein, editors, Handbook of Public Economics, Vol. 4, (Amsterdam: Elsevier), 2002.

Geanakoplos, John, Olivia S. Mitchell and Stephen P. Zeldes, "Would a Privatized Social Security System Really Pay a Higher Rate of Return?” In Framing the Social Security Debate: Values, Politics and Economics. Eds. D. Arnold, M. Graetz, and A. Munnell. Brookings Institution, 1998: 137-157.

Gruber, Jonathan and David A. Wise, Eds. Social Security and Retirement Around the World. National Bureau of Economic Research, (University of Chicago Press) 1999.

Gruber, Jonathan and David A. Wise. "Social Security and Retirement: An International Comparison.” American Economic Review, 88(2), 1998: 158-163

Hubbard, R. Glenn and Kenneth L. Judd. "Social Security and Individual Welfare: Precautionary Saving, Borrowing Constraints, and the Payroll Tax.” American Economic Review, 77(4) 1987: 630-646

James, Estelle and Sarah M. Brooks. "The Political Economy of Structural Pension Reform.” In New Ideas About Old Age Security. Eds. R. Holzmann and J. Stiglitz, Washington D.C: World Bank, 2001.

Kotlikoff, Laurence J., Torsten Persson, and Lars E. O. Svensson. "Social Contracts as Assets: A Possible Solution to the Time-Consistency Problem.” American Economic Review, 78(4) 1988: 662-677

Kotlikoff, Laurence J., Kent Smetters and Jan Walliser. "Privatizing Social Security in the United States - Comparing the Options.” Review of Economic Dynamics, 2(3) 1999: 532574

Laitner, John. "Social Security Reform and National Wealth.” Scandinavian Journal of Economics, 102 (3), 2000: 349 - 371

Mariger, Randall P. "Social Security Privatization: What Are the Issues?" National Tax Journal, 52(4) 1999: 783-802

Mesa-Lago, Carmelo. Social Security in Latin America: Pressure Groups, Stratification, and Inequality. University of Pittsburgh Press. Pittsburgh, USA. 1978

Nishiyama, Shinichi, and Kent Smetters. "Does Social Security Privatization Produce Efficiency Gains?” Quarterly Journal of Economics, 122(4), 2007: 1677-1719 
Rangel, Antonio. "Forward and Backward Intergenerational Goods: Why Is Social Security Good for the Environment?” American Economic Review, 93(3), 2003: 813-834

Samuelson, Paul. "An Exact Consumption-Loan Model of Interest With or Without the Social Contrivance of Money.” Journal of Political Economy, 66(6), 1958: 467-482

Social Security Programs Throughout the World. The International Social Security Association and the U.S. Social Security Administration. Geneva, Switzerland and Washington D.C., United States. Various editions.

Smetters, Kent. "Is the Social Security Trust Fund A Store of Value?” American Economic Review, 94(2) 2004: 176-181

Verbon, Harrie A.A., The evolution of public pension schemes. Springer: Berlin. $1998 a$.

Verbon, Harrie A.A., "Explaining pay-as-you-go financed public pension systems," Economics Letters, 28 1998b: 181-187.

Walker, Eduardo and Fernando Lefort. "Pension Reform and Capital Markets: Are There Any (Hard) Links?” ABANTE, 5(2) 2002: 77-149

Zollner, Detlev. “Germany.” In The Evolution of Social Insurance 1881-1981: Studies of Germany, France, Great Britain, Austria and Switzerland. Eds. P. Kohler, H. Zacher and M. Partington. Max-Planck Institute for Foreign and International Social Law. St. Martin's Press, New York, USA. 1982. 
(Countries in Bold reformed their state pension systems as of 2003)

\begin{tabular}{|c|c|c|c|}
\hline No Instability (0) & Low (1) & Low-Moderate (2) & Moderate (3) \\
\hline Australia & Armenia & Albania & Bolivia \\
\hline Bangladesh & Azerbaijan & Algeria & Bulgaria \\
\hline Botswana & Bahrain & Austria & Burkina Faso \\
\hline Canada & Belarus & Belgium & Dominican Republic \\
\hline Costa Rica & Burundi & Benin & El Salvador \\
\hline Haiti & Cameroon & Central African Rep. & France \\
\hline Israel & Chad & Colombia & Greece \\
\hline Jamaica & China & Congo & Guyana \\
\hline Laos & Cote d'Ivoire & Cyprus & Hungary \\
\hline Lebanon & Dem. Rep. Congo & Denmark & Iran \\
\hline New Zealand & Egypt & Ethiopia & Latvia \\
\hline Niger & Equatorial Guinea & Gabon & Mexico \\
\hline Oman & Estonia & Germany & Panama \\
\hline Saudi Arabia & Finland & Ghana & Philippines \\
\hline Sierra Leone & Georgia & Guinea & Poland \\
\hline Switzerland & Honduras & Italy & Venezuela \\
\hline United Kingdom & Ireland & Kyrgyzstan & \\
\hline United States & Japan & Lithuania & High (4) \\
\hline Vietnam & Jordan & Madagascar & Czech Republic \\
\hline \multirow[t]{17}{*}{ Zimbabwe } & Kazakhstan & Mali & Ecuador \\
\hline & Kuwait & Morocco & Guatemala \\
\hline & Mauritania & Netherlands & Paraguay \\
\hline & Mauritius & Nicaragua & Peru \\
\hline & Norway & Pakistan & Romania \\
\hline & Portugal & Republic of Korea & Slovakia \\
\hline & Moldova & Russian Fed. & Spain \\
\hline & Senegal & Rwanda & \\
\hline & South Africa & Sudan & Very High (5+) \\
\hline & Sweden & Tunisia & Brazil \\
\hline & Syria & Ukraine & Chile \\
\hline & Thailand & & Croatia \\
\hline & Togo & & Slovenia \\
\hline & Trinidad and Tobago & & Turkey \\
\hline & Turkmenistan & & Uruguay \\
\hline & Uzbekistan & & Argentina \\
\hline & Yemen & & \\
\hline
\end{tabular}


Some countries, like Chile, have replaced their entire pension system with private accounts, while other countries have chosen to retain significant elements of their existing public pension systems and use private accounts as a supplementary source of retirement income. We construct an actuarial model of the future share of pension payments that will be derived from the privatized portion of the social security system. This produces a scaled reform variable that ranges from 0 to 1 , with 1 indicating that $100 \%$ of future pension payments in that country will come from private accounts. We model all countries with private account reforms in our dataset.

First, we collected the published rules of the private account system and the complementary public pension system after reform. These rules include the contribution rates to the private and public pension system, the retirement age, and the payout formulas used for the public pension system (Social Security Programs Throughout the World, Various Editions). Next, we obtain detailed data on the income distribution of the country, and life expectancy by gender (WDI World Development Indicators 2004). We use the income distribution data to construct country wages by income percentile, and then model contributions into a private account for a typical worker of a given income percentile. At retirement, the worker's private account, with compounded returns, is used to buy an annuity. The cost of the annuity is actuarially calculated based on the country-specific life table. The annual value of the annuity is the yearly income attributable to the private account component of the pension system. We add to this annuity the annual value of the payment provided by the public component of the pension system, as determined by the rules of the country's public pension system, to obtain the total annual income available to the worker at retirement. The percentage of this total value which is derived from the private account component is the scaled reform variable, which ranges from 0 for no reform to 1 , representing $100 \%$ reforms with all retirement income derived from the 
private accounts. Since contribution rates may differ by income by country, we perform this calculation at different income percentiles for each country, and obtain the average scaled reform percentage, which corresponds closely to the percentage of income derived from private accounts for the median wage earner.

A simplified structural representation of our modeling process is given by:

$$
\text { REFORMPCT } \left._{i}=\text { PRIVATEPENSION }_{i} / \text { [PRIVATEPENSION }_{i}+\text { GOVTPENSION }_{i}\right]
$$

Where:

REFORMPCT $_{i}=$ The percentage of retirement income from private account sources for a representative retiree in income percentile $i$ (subsequently appropriately weighted to determine the average country-wide percentage of retirement income from private account sources)

GOVTPENSION $_{i}=$ Sum of annual country-specific government-administered, publicly financed transfer payments including specific old age welfare programs and minimum pension guarantees, to a representative retiree in income percentile i

PRIVATEPENSION $_{i}=$ Value of the annuity purchased with accumulated private account contributions by the representative retiree in income percentile i:

\section{AWUAL VALUE OF PREATE COMPONGNT

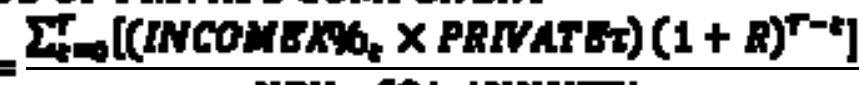 NPV of $\$ 1$ ANUTrY}

where:

$$
\begin{aligned}
& \text { PRIVATE } \tau=\text { Private account contribution tax rate } \\
& \text { INCOMEX } \%_{t}=\text { Annual labor income at the Xth percentile of wages in period } \mathrm{t} \\
& \mathrm{R}=\text { Real rate of return on private account funds, set to } 3 \% \\
& \mathrm{~T}=\text { Labor Income Periods till Retirement Age (assuming working life begins at age 20) }
\end{aligned}
$$

Note that our modeling process differs by country due to structural differences such as the country's tax rates on retirement income (if any), contribution ceilings, floors, and caps, 
guaranteed minimum income plans, and the like. Two major pension system features and their modeling decisions are given below:

Redistributive Payments: Many countries explicitly include redistributive elements in their pension systems. These often take the form of a minimum pension guarantee or other old-age transfers. These transfers are financed by the government, and thus are excluded from calculations of the private system's share of overall pension payments, even when the transfer is paid out 'through' the private system. In general, redistributive elements will decrease the share of pensions attributable to the private system when the income distribution of the country is such that a large number of workers will likely qualify for redistributive payments.

Voluntary Participation / Switching Between Systems: Under some systems, workers have a choice of participating in the new system or old system, or even of switching between new and old systems at certain times. Generally, this choice of participation is limited by age group, so older workers have the ability to opt-in while younger workers generally must switch to the new system. For simplicity, for all reforms that include age-related opt-outs, we assume that the system is fully transitioned to younger workers when modeling private system payouts. However, for reforms that give workers the ability to continuously choose which system to participate in, we model the NPV of each system choice for a representative worker of that income group, and have the worker choose the system which offers them the higher NPV at that point in time.

The spreadsheets used in calculating each country's scaled reform variable are available from the authors. 
Appendix C: Variable Definitions and Sources for Empirical Estimation (Section 4)

\begin{tabular}{|c|c|}
\hline Variable & Description / Source \\
\hline Instability & $\begin{array}{l}\text { Based on the DURABLE variable from the Polity IV Project: } \\
\text { Political Regime Characteristics and Transitions, 1800-2006 } \\
\text { database. DURABLE is a country by year level observation that } \\
\text { indicates the number of years since the last regime change in that } \\
\text { country. Instability measures the number of times, since the creation } \\
\text { of that country's public pension system, that DURABLE reaches } 5 . \\
\text { Thus, Instability is higher for countries with frequent regime changes. }\end{array}$ \\
\hline $\begin{array}{l}\text { WDI: Annual Per Capita } \\
\text { PPP GDP in 1,000s } \\
\text { (Inter/Expolated) }\end{array}$ & $\begin{array}{l}\text { Based on NYGDPPCAPPPKD from the World Development } \\
\text { Indicators } 2005 \text { database from the World Bank. Annual Per-Capital } \\
\text { Purchasing Power Parity GDP, in } \$ 1,000 \text { s of dollars. Due to data } \\
\text { continuity problems, data is interpolated and extrapolated when } \\
\text { necessary to ensure a balanced panel for estimates. }\end{array}$ \\
\hline $\begin{array}{l}\text { WDI: Annual \% Of } \\
\text { Population } 65+\end{array}$ & $\begin{array}{l}\text { Obtained from SPPOP65UPTOZS from the World Development } \\
\text { Indicators } 2005 \text { database from the World Bank. Percentage of the } \\
\text { country's total population in that year who are aged } 65 \text { years and } \\
\text { older. }\end{array}$ \\
\hline $\begin{array}{l}\text { UN Projected } \\
\text { Population } 65+\text { in } 2025, \\
\text { Percent of Total } \\
\text { Population }\end{array}$ & $\begin{array}{l}\text { Obtained from World Population Prospects, the } 2004 \text { Revision, } \\
\text { Medium Variant. United Nations Population Division. }\end{array}$ \\
\hline Historic Democracy & $\begin{array}{l}\text { Based on the POLITY2 variable from the Polity IV Project database. } \\
\text { POLITY2 is a country by year level observation that ranges from }+10 \\
\text { (strongly democratic) to - } 10 \text { (strongly autocratic). Historic } \\
\text { Democracy is the average historical POLITY2 score for the period } \\
\text { between the creation of that country's public pension system, and the } \\
\text { year of reform or the year 2003, whichever comes first. }\end{array}$ \\
\hline $\begin{array}{l}\text { WDI: Domestic Credit } \\
\text { to Private Sector, \% of } \\
\text { GDP }\end{array}$ & $\begin{array}{l}\text { Based on FSASTPRVTGDZS from the World Development } \\
\text { Indicators } 2005 \text { database from the World Bank. Domestic Credit to } \\
\text { Private Sector refers to financial resources provided to the private } \\
\text { sector, such as through loans, purchases of nonequity securities, and } \\
\text { trade credits and other accounts receivable that establish a claim for } \\
\text { repayment. For some countries these claims include credit to public } \\
\text { enterprises. Domestic Credit to Private Sector is divided by country's } \\
\text { GDP and expressed as a multiple of GDP. }\end{array}$ \\
\hline $\begin{array}{l}\text { WDI: Annual } \\
\text { Interpolated and } \\
\text { Extrapolated Life } \\
\text { Expectancy }\end{array}$ & $\begin{array}{l}\text { Based on SPDYNLE00IN from the World Development Indicators } \\
2005 \text { database. SPDYNLE00IN is a country by year observation } \\
\text { indicating that country's current life expectancy at birth. Due to data } \\
\text { continuity problems, we interpolate and extrapolate this variable to } \\
\text { form a continuous series. }\end{array}$ \\
\hline
\end{tabular}

